\title{
What We Know and What We Do Not Know about Dragon Trees?
}

\author{
Petr Maděra ${ }^{1, *}\left(\mathbb{0}\right.$, Alan Forrest $^{2}$, Pavel Hanáček ${ }^{3}$, Petr Vahalík ${ }^{4}$, Roman Gebauer ${ }^{1}$, \\ Roman Plichta ${ }^{1}$, Radek Jupa ${ }^{1}$, Julian Jansen Van Rensburg ${ }^{5}{ }^{(\mathbb{D}}$, Miranda Morris ${ }^{6}$, \\ Nadezhda Nadezhdina ${ }^{1}$, Lucie Vaníčková ${ }^{1}$, Joanna Jura-Morawiec ${ }^{7}$, \\ Justyna Wiland-Szymańska ${ }^{8}$, Hana Kalivodová ${ }^{1}$, Klára Lengálová ${ }^{1}$, Martin Rejžek ${ }^{1}(\mathbb{D}$ and \\ Hana Habrová ${ }^{1}$ (D) \\ 1 Department of Forest Botany, Dendrology and Geobiocoenology, Faculty of Forestry and Wood Technology, \\ Mendel University in Brno, Zemědělská 1, Brno 613 00, Czech Republic; roman.gebauer@mendelu.cz (R.G.); \\ roman.plichta@mendelu.cz (R.P.); r.jupa@mail.muni.cz (R.J.); nadezda.nadezdina@mende (N.N.); \\ luci.vanickova@gmail.com (L.V.); hanakalivodova@seznam.cz (H.K.); klara.lengalova@mendelu.cz (K.L.); \\ martin.rejzek@mendelu.cz (M.R.);hana.habrova@mendelu.cz (H.H.) \\ 2 Centre for Middle Eastern Plants, Royal Botanic Garden Edinburgh, 20a Inverleith Row, \\ Edinburgh EH3 5LR, Scotland, UK; AForrest@rbge.org.uk \\ 3 Department of Plant Biology, Faculty of Agriculture, Mendel University in Brno, Zemědělská 1, \\ Brno 613 00, Czech Republic; hanacek@mendelu.cz \\ 4 Department of Forest Management and Geoinformatics, Faculty of Forestry and Wood Technology, \\ Mendel University in Brno, Zemědělská 1, Brno 613 00, Czech Republic; petrvahalik@seznam.cz \\ 5 Freie Universität Berlin, Kaiserswerther Str. 16-18, 14195 Berlin, Germany; \\ jansenvanrensburg.julian@gmail.com \\ 6 School of History, University of St. Andrews, St. Katharine's Lodge, St. Andrews KY16 9BA, Scotland, UK; \\ miranda@mirandamorris.com \\ 7 Polish Academy of Sciences Botanical Garden-Centre for Biological Diversity Conservation in Powsin, \\ Prawdziwka 2, 02-973 Warsaw, Poland; j.jura@gazeta.pl \\ 8 Department of Systematic and Environmental Botany, Faculty of Biology, Adam Mickiewicz University, \\ Uniwersytetu Poznańskiego 6, 61-614 Poznań, Poland; wiland@amu.edu.pl \\ * Correspondence: petrmad@mendelu.cz; Tel.: +420-5451-34060
}

Received: 11 January 2020; Accepted: 18 February 2020; Published: 21 February 2020

\begin{abstract}
This article is a broad review focused on dragon trees-one of the most famous groups of trees in the world, well known from ancient times. These tertiary relicts are severely endangered in most of the area where they grow. The characteristic features of the dragon tree group are described and the species belonging to this group are listed. This review gathers together current knowledge regarding the taxonomy, evolution, anatomy and morphology, physiology, and ontogeny of arborescent dragon tree species. Attention is also paid to the composition, harvesting, medicinal, and ethnobotanical use of the resin (dragons' blood). An evaluation of population structure, distribution, ecology, threats, and nature conservation forms the final part of the review. In the conclusions we recommend further avenues of research that will be needed to effectively protect all dragon tree species.
\end{abstract}

Keywords: Dracaena; arborescent form; dragon tree group; taxonomy; anatomy; morphology; ecophysiology; distribution; ecology; ethnobotany; threat; nature conservation

\section{Introduction-Dragon Trees, Tertiary Relicts in Current Reality}

Dragon trees are one of the most famous groups of trees in the world, well known from ancient times. Their distinctive habit, adaptation to arid condition, and especially the red resin (dragon's 
blood) that they exude have had a long effect on human imagination and curiosity. Only a few species among more than 60-190 species of the genus Dracaena [1-3] reach arborescent form. Marrero et al. [4] classified such species as the dragon tree group. Members of the dragon tree group are usually defined by a few general traits, which are: arborescent habit, excretion of the red resin, leaving a closely packed pattern on the bark, closely packed leaves at branch apices with a lack of distinctive internodes, leaf sheaths differentiated in colour, very succulent leaves with a large amount of a water tissue and fibers, leaf blades lacking a distinctive costa, thick cuticle on the leaves, flowers usually diurnal with a perianth not elongated into a tube, and the filaments of the stamens inserted at the tepal bases with thickened filaments [4,5]. In this review, the species considered as belonging to the dragon trees are: Dracaena cinnabari Balf.f., D. draco L. subsp. draco, D. draco subsp. caboverdeana Marrero Rodr. \& R. Almeida, D. draco subsp. ajgal Benabid \& Cuzin, D. tamaranae A. Marrero, R. S. Almeida et M. González-Martín, D. ombet Heuglin ex Kotschy \& Peyr., D. ombet subsp. schizantha Baker, D. serrulata Baker, and D. ellenbeckiana Engl. present in Macaronesia, North Africa, and South Arabia [4-8]. The other species that are recognized as dragon trees are found in South East Asia [9-11]: D. jayniana Wilkin \& Suksathan, D. cochinchinensis (Lour.) S. C. Chen, D. yuccifolia Ridl., D. cambodiana Pierre ex Gagnep., and D. kaweesakii Wilkin \& Suksathan. We exclude the American species (D. americana Donn. Sm., D. cubensis Vict.) [12], as they do not produce the red resin and their morphology is not fully known. The dragon tree group is significant for many different reasons, the most important of which are:

- Dragon trees are tertiary relict species [13], and the ecosystems (woodlands and very rare forests) being of middle Oligocene to Miocene origin to which these species belong to are one of the evolutionary oldest ecosystems in the world [14].

- $\quad$ Some species are locally endemic with limited (often island) distribution $[4,7,15,16]$.

- The distribution of most species is scattered, comprising a small population with unbalanced age structure, and young trees often bring absent $[8,9,11,17-21]$.

- $\quad$ Some species are threatened and are listed in the IUCN Red List [22]. In fact, of the six species that have been assessed, five are threatened, while the other 11 species have not yet been assessed.

- The natural regeneration of most species is being destroyed by decades of overgrazing [17,20,23-26].

- Dragon trees are strongly susceptible and vulnerable to the effects of climate change (drought, cyclones) $[11,18]$.

- Most species have been from ancient times as an important source of non-timber products (resin, fodder for cattle, and forage for bees, leaves used for rope production), thus belong to the cultural heritage of humanity $[17,27]$.

- Dragon trees are flagship and umbrella species hosting many other organisms, including endemic taxa, which are totally dependent on dragon trees [28-30].

- Dragon trees strongly and positively influence the hydrology cycles in the landscape [20,31].

- Most species are present in developing countries with an unstable political situation, and populations are under pressure, as weak governments have insufficient resources to protect them.

- Dragon trees often provide local income through ecotourism by being aesthetically attractive species, popular with visitors. In addition, some species are commonly sold as attractive indoor plants $[11,19,32]$.

The main objective of the present article is to collect all published results of research that is focused on the dragon tree species and, based on its detailed evaluation, to determine the key gaps for future investigation as a basis for conservation management.

\section{Evolution, Taxonomy and Distribution}

\subsection{Current Taxonomical Knowledge and Nomenclature}

The genus Dracaena Vand. ex L. is placed in the family Asparagaceae subfamily Nolinoideae [33,34]. It is considered to be monophyletic based on molecular studies [35], and it comprises 190 species [3]. 
The taxonomic boundaries and proper author of the name of the genus are still debated. Kuntze conducted an analysis of the original name of this genus [36]. He has pointed out that the first published name for the dragon tree from the Canary Islands was Draco Heist., due to its publication in 1748. It was prior to the Linneaus first inclusion of this species into the genus Asparagus L. as Asparagus draco L. (Sp. Pl. ed. 2, 1776: 451). Later, Linnaeus decided to credit a new name for a dragon tree to Vandelli, bacause of his extensive treatment of this species (Dissertatio de Arbore Draconis seu Dracaena in Roemer Scriptores, 1796: 39) [36,37]. However, Kuntze pointed out that Vandelli called the dragon tree Draco yucciformis, adding Dracaena as a synonym. Moreover, Linnaeus has included in the genus Dracaena several species, which were later transferred to Terminalis Medik., Dianella Lam. ex Juss and Liriope Lour. In conclusion Kuntze has pointed out, that all species of Dracaena shall be transferred into the genus Draco Heist., which he did accordingly.

The systematics of the dracenoid clade of Asparagaceae [34] is so far not completely agreed upon. Currently, all species previously described in the genera Sansevieria Petagna and Pleomele Salisb. have been transferred to Dracaena [3]. DNA analysis showed that Dracaena clade includes genus Pleomele Salisbury. Brown [38] separated it based on differences in the division of perianth parts and filament thickness but these traits showed as convergent with Sansevieria [33]. Species of Pleomele are intermixed into Dracaena clade so based on taxonomic view should be renamed as Dracaena because of the priority of the Dracaena genus name Vandelli ex Linnaeus (1767) in comparison with Pleomele Salisbury (1796). Molecular studies point out that the species of Sansevieria create a clade within Dracaena [33]. By other scientists, Sansevieria is still treated as a separate genus [38-41] due to its different morphological, palynological, and carpological characters. Although morphologically Sansevieria members are easily recognizable, all of the tested members form a monophyletic clade sitting deeply in Dracaena phylogram [33,42]. Hawaian species of the genus Pleomele, unique in their morphology and pollination patterns, are now separated as a genus Chrysodracon (Jankalski) P.-L. Lu \& Morden [33]. They form a monophyletic clade at a base of the Dracaena, and they are regarded as a sister group to all other dracenoids [33]. Further molecular and morphological studies on infrageneric division are certainly needed.

There is some confusion as to the identification and relationships among Dracaena species in Arabia. Three sub-species of D. serrulata have been described [17], but without a systematic comparison among populations, and even, in fact, suggesting some sub-species have a similar habit to D. ombet. Detailed and systematic studies of morphological characters and population level molecular studies are required to resolve these issues.

As Dracaena draco was the type species for the genus name, we can for now conclude that the genus name Dracaena is proper for the dragon trees, as enumerated in this paper.

\subsection{Evolution of Arborescent Dracaenas}

The dragon tree group of Dracaena does not form a monophyletic clade within Dracaena in any molecular studies, despite morphological analyses [33]. This suggests that differences in arborescent Dracaena habit are homoplasious, so arborescence could have independently arisen during evolution of Dracaena genus repeatedly [33]. Dracaena cinnabari appears to be evolutionary the most basal member of the dragon tree group. The more recent clade is a group of Macaronesian species (D. draco and D. tamaranae) and the last group are members from East Africa and the Arabian Peninsula (D. ombet subsp. ombet, D. ombet subsp. schizantha, and D. serrulata). Based on morphological similarities $[43,44]$ as well as DNA analyses (our unpublished data), D. ombet subsp. schizantha display some similarities not only with $D$. ombet subsp. ombet, but also with $D$. cinnabari. These facts in combination with geographical area of occurrence of these three taxa presumably demonstrate to horizontal gene flow between $D$. ombet and D. cinnabari during D. ombet subsp. schizantha speciation. However, it must be noted that molecular studies disagree in the resolution and placement of many dragon tree taxa, and that differences in clade composition occur, depending on the markers and analyses employed, and the species sampling might also affect some results. 
The fossil record of Dracaena is rather poor. Two genera, Dracaenophyllum Massalongo and Dracaenites Saporta, are regarded as close relatives of contemporary members of the genus Dracaena [13,45]. Some fossils are described as belonging to Dracaena itself: D. saportae Van Campo \& Sivak, D. guinetii Van Campo \& Sivak, and D. taifunii Denk et al. [13]. They were described from the Tertiary based on bark and leaf imprints or palynomorphs from the Canary Islands, Italy, France, Bohemia, Tunisia and Turkey $[13,45]$. These fossils create a basis for further phylogenetic studies, when our knowledge of micromorphological characters will be sufficient for comparison with contemporary species.

The $t r n \mathrm{~L}-\mathrm{F}$ region ( $t r n \mathrm{~L}$ intron and $t r n \mathrm{~L}-t r n \mathrm{~F}$ intergenic spacer) and $r p s 16$ intron, and the low-copy nuclear region At103 dragon trees were also compared in the phylogenetic studies of Sansevieria while using chloroplast sequences and nucleotide sequences of two non-coding plastid DNA regions [42,46]. In the analysed genomes of the following species were included: D. draco, D. ellenbeckiana, D. jayniana, D. kaweesakii, and D. multiflora. Their subclade resolved as the earliest diverging lineage in nDNA analyses, but also contained Chrysodracon konaensis from Hawaii. In this case, a deeply nested position within the phylogeny presented means that the recognition of Chrysodracon would again render Dracaena paraphyletic [42].

The analysis of six Asian species of Dracaena based on the chloroplast genomes has revealed that their structure and composition are highly similar. It has been suggested that the chloroplast genome can be used as a barcode for this genus, although sampling was low and specific details of the distinction between taxa was not given, as well as an absence of formal barcoding analyses to demonstrate a reliable differentiation between species. This study has also revealed a close relationship betwen $D$. cambodiana and D. cochinchinensis, which form a separate clade in the Dracaena taxa studied [47].

A complete plastome was elaborated for D. cambodiana [48]. This species was also studied as to its haplotypes diversification based on nucleotide sequence data of two chloroplast DNA (cpDNA: $a t p \mathrm{~B}-r b c \mathrm{~L}$ and $t r n \mathrm{D}-t r n \mathrm{~T}$ ) regions and genotype data of six nuclear microsatellites from 15 populations [49].

The dragon trees produce flowers with divided tepals, and filaments of stamens centrally thickened, which distinguishes them from other closely related species of Dracaena and Sansevieria that produce an elongated flower tube [38]. The pollen grains of plants from the dragon tree group were studied for: D. cambodiana, D. draco, D. ellenbeckiana, D. multiflora, D. ombet subsp. ombet, D. ombet subsp. schizantha, and D. serrulata [44].

\subsection{Geographical Distribution}

The dragon tree group members are restricted to West and East Africa, Arabia and adjacent islands. Two species are found in Macaronesia and NW Africa: D. draco and D. tamaranae; the rest of the species are found in East Africa, Arabia and Soqotra (Figure 1).

D. draco with its three subspecies is distributed in Macaronesia and African Anti-Atlas. The subspecies D. draco subsp. ajgal grows in western part of Anti-Atlas, where thousands of individuals were observed between Jebel Imzi (1540 m a.s.1.) and Adad Medni (1395 m a.s.1.) peaks-NE of Anezi and E of Tiznit, around the gorges of Assif Oumarhouz stream at an area of circa 500 ha [8]. D. draco subsp. caboverdeana is native to the Cape Verde Islands, which has, until today, naturally grown on Santo Antão, São Nicolau, and Fogo islands on the windward NE slopes at elevations of 50-1400 m a.s.l. It is extinct in the wild on Santiago and São Vicente islands. It sub-spontaneously grows on Santiago and Brava and is cultivated on all Cape Verde islands [7,50]. D. draco subsp. draco is native on Madeira Islands (still on Madeira at elevations 0-200 m a.s.l., but is extinct on Porto Santo island). On the Canary Islands it still grows naturally on the islands of Tenerife (between 100 and $600 \mathrm{~m}$ a.s.1.) and on the NE part of Gran Canaria Island. The species is extinct in wild on El Hierro, La Gomera, and La Palma, and also on Azores. Nevertheless, it is cultivated on all Canary Islands, Azores, and Madeira [51-54]. 


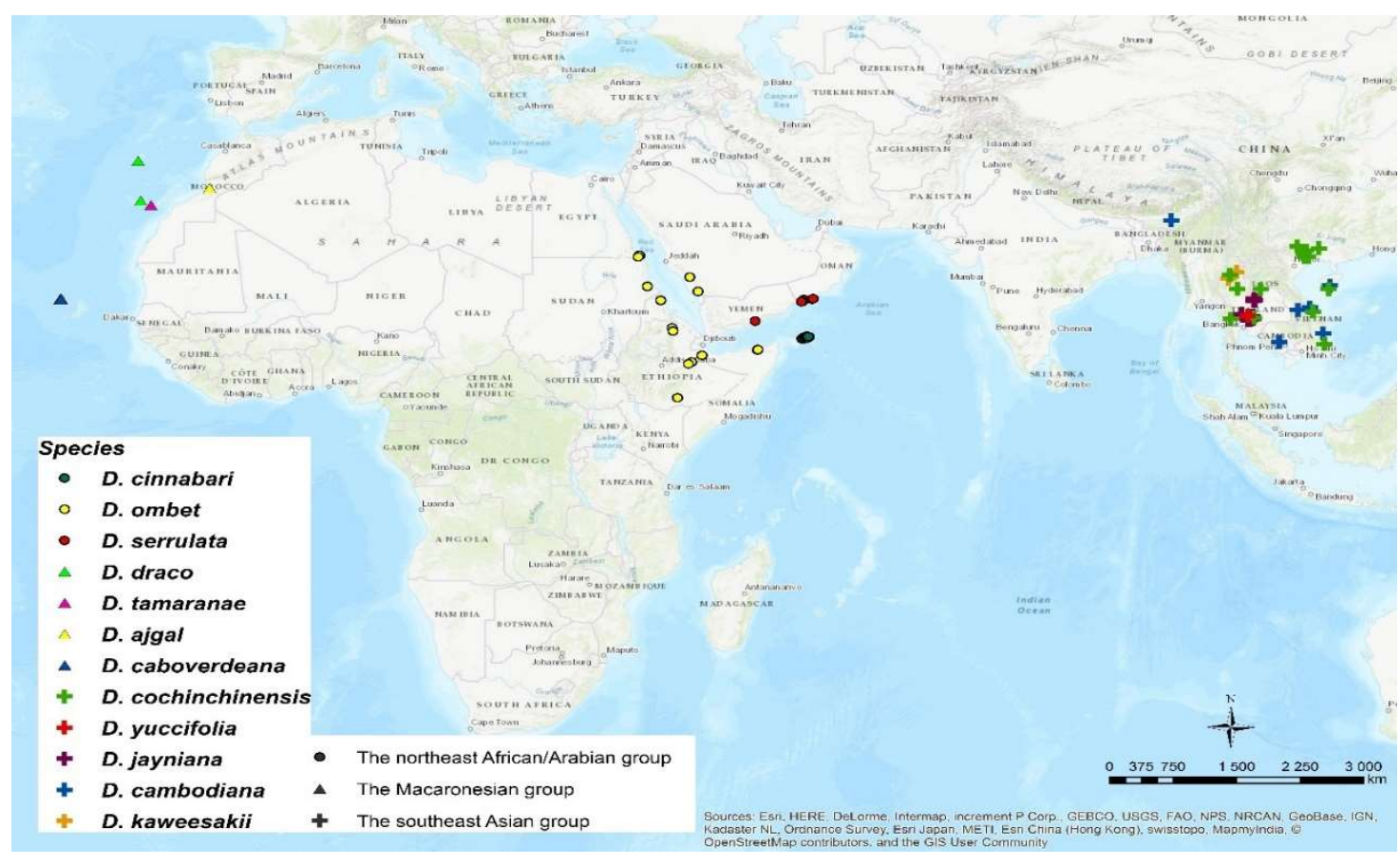

Figure 1. Geographic distribution of individual dragon tree species, the points show locality of occurrence based on published sources cited in this Section 2.3.

D. tamaranae is endemic to Gran Canaria Island, where it grows in a limited area in the south-east part at elevations of 340 and $1270 \mathrm{~m}$ asl. [4,16].

D. cinnabari forms the densest forest and woodland populations on Soqotra Island (Yemen). Isolated populations of D. ombet and D. serrulata are found in mountainous areas of Egypt, Sudan, Eritrea, Ethiopia, Djibouti, Somalia, Saudi Arabia, mainland Yemen, and Oman.

On Soqotra, the forests of D. cinnabari trees are found on the Firmihin plateau, while open woodlands cover large part of limestone plateaux from $450 \mathrm{~m}$ a.s.l. on Diksam, Shibehon, Hamadero, Kilim, Sirhin, etc., and admixed with other trees are found in Haggeher mountains up to $1500 \mathrm{~m}$ a.s.l. $[55,56]$.

Arabian species of D. serrulata grows in southern Arabia (SW Yemen, southern and SE Oman, and southern Saudi Arabia). It has a scattered distribution along the southwestern edge of the Arabian Peninsula, mainly in the hills of southern Medina and the El Asir mountains in Saudi Arabia; in the foothills of the highlands of Yemen, and on northern slopes of Dhofar in Oman $[4,17,57,58]$.

D. ombet is native to Egypt, Sudan, Eritrea, Djibouti, Ethiopia, Somalia, and possibly Saudi Arabia, being distributed in the mountain range facing the Red Sea $[4,59,60]$. Currently, it is divided into two subspecies as former individual species $D$. schizantha has been included into $D$. ombet as a subspecies [3]. D. ombet subsp. ombet naturally occurs in mountainous regions along the African hills that face the Red Sea. It is found in Gebel Elba and Gebel Shindeeb in SE Egypt, escarpments of the Eritrean mountains; it still grows in Mount Erkowit in Sudan, and its presence has also been confirmed in Saudi Arabia [59-63]. D. ombet subsp. schizantha is found in north-facing escarpments of Harar in Ethiopia, in Goda Mountain and Ghoubbe mountains of Djibouti and in the mountains of northern Somalia to the Ahl Mountains, where it almost reaches the Horn of Africa [61,64,65].

Asian group members contain five arborescent species. D. cambodiana is native in $\mathrm{S}$ and $\mathrm{W}$ of Hainan island, in Guangxi and Yunnan provinces (all in southern China), in Thailand, Laos, Cambodia, Vietnam, and E India $[49,66,67]$. D. cochinchinensis grows in Yunnan and Guangxi provinces in China, in Vietnam, and Laos [68,69]. D. jayniana is endemic to central and NE Thailand [9]. D. kaweesakii is native in $\mathrm{N}, \mathrm{NE}$, and central Thailand and adjacent eastern Myanmar [10]. D. yuccifolia grows in Ratchaburi in Thailand to Langkawi in Malaysia [10]. 


\section{Morphology and Anatomy}

\subsection{Dracaena Habitus/Shape and its Modifications by Environmental Factors}

Dragon trees possess a tree-like form with an umbrella-like appearance in the mature individual. Its canopy consists of several orders of branches that are topped with a long-lived rosette of leaves [70]. Leaves within the rosettes can be flexible (e.g., D. draco) or rigid (e.g., D. cinnabari), while their length varies according to the species, site condition, and tree ontogeny [4]. Little is known regarding the morphology of the root system of the dragon trees, as it is not easily obtained for study. The roots of Dracaena species are adventitious in origin and they are unique among monocots as they undergo secondary growth [71,72]. Hubálková et al. [73] noted that the successive growth of $D$. cinnabari trees is accompanied by the development of horizontal roots, which run far beyond the vertical projection of the crown. As most of the horizontal roots are found within the upper $30 \mathrm{~cm}$, they are potentially prone to injury by overheating and dehydration [74].

The key factor determining the height of the trunk and the shape of the Dracaena crown is sunlight $[75,76]$. The regular umbrella-like crown is formed in full sunlight, but asymmetrical crown develops under the condition of unidirectional, oblique sunlight [70,76]. Moreover, the branching of the dragon tree is correlated with flowering [76], but it could also be initiated by the decapitation of the main stem [77,78]. In some Dracaena species, the regular growth form might also be modified by the development of aerial roots [74] (Figure 2a). The function of aerial roots in D. draco is not clear. It is supposed that they absorb water from the atmosphere and are initiated in response to water stress or damage $[74,79,80]$. Aerial roots were observed in some individuals of $D$. cinnabari [81], D. draco [79,82] (Figure 2a), and D. ellenbeckiana (Jura-Morawiec unpubl.), although information regarding the occurrence of aerial roots in other Dracaena species is missing.
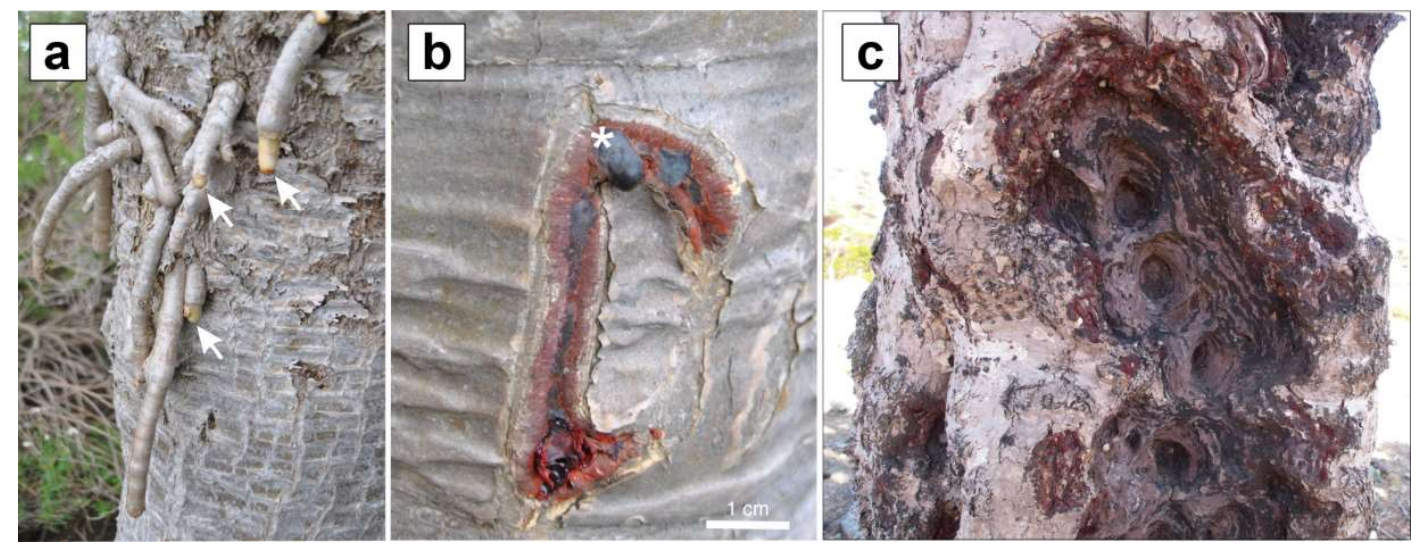

Figure 2. Aerial roots and dragon's blood of a dragon tree. (a) D. draco, aerial roots arising from the stem with growing tips (arrows). (b) D. draco, wound of stem with a tear-like drop of dragon's blood (asterisk). The rest of the wound is covered with resin that can be removed in a form of chips. (c) D. cinnabari, ancient wounds tapping until now.

\subsection{Leaf Micromorphology and Anatomy-From Mesomorphic to Xeromorphic Leaves}

The available information does show quite high variability in Dracaena leaf structure, which reflects wide distribution of different Dracaena species across many habitats from the wet to dry forests of the Old World tropics to the semi-desertic habitats of the Mediterranean [83]. The leaf microstructure of Dracaena species ranges from mesomorphic to xeromorphic. Mesomorphic traits are the slightly bulging stomata, or stomata that are located at the level of other epidermal cells (e.g., D. draco, D. kaweesakii) [43,84] (Figure 3d), although slightly sunken stomata could also be observed (e.g., D. jayniana) [43]. Such stomata are more or less distributed in rows (D. draco, D. tamaranae, D. jayniana) [43,84], but the entirely scattered stomata were also observed (D. kaweesakii) [43]. The 
cuticle of more mesomorphic species is thinner, ranging approx. from 1 to $13 \mu \mathrm{m}$ and fiber bundles are mostly hypodermal $[43,84,85]$ (Figure 3b). The drought resistance of these species could also be very high, despite the more mesomorphic appearance, as a recent study on young transplants of mesophytic $D$. marginata confirmed [86]. The xeromorphic species have more deeply sunken stomata (D. ombet, D. serrulata, and D. cinnabari) (Figure 3c), which are distributed irregularly or parallel to the leaf axis regularly over the entire area $[13,43,84]$. Sunken stomata are mostly surrounded by cuticular thickenings forming a rim, which appears square, oval, or rectangular in outline [43]. The epicuticular waxes are thicker, ranging from approx. 14 to $22 \mu \mathrm{m}[43,84]$. The fiber bundles are located in mesophyll and are presented more frequently, which provides higher rigidity to the leaves [43,84]. In general, and independently to habitats, the types of stomata are mostly tetracytic (e.g., D. cinnabari; D. jayniana), but anomocytic stomata have been also observed (e.g., D. draco; D. kaweesakii) [43,87]. Dracaena leaves are mostly amphistomatic with stomata on both leaf sides [43,84] (Figure 3a,b), but hypostomatic leaves with stomata on only the adaxial side were also observed (e.g., D. ellenbeckiana) [87]. The stomatal density varies along the leaf axis as well as between midrib and leaf margins [84,86] and, in general, the stomatal density increases towards the more xeromorphic appearance (approx. 30-90 stoma per $\mathrm{mm}^{2}$ ) [84,86]. Higher stomatal density was mostly observed on the abaxial leaf side [87]. The cuticle on the adaxial epidermis is usually thicker than on the abaxial one [43] and its quite smooth, though papillae structures, which were also observed in D. ombet and D. cinnabari and irregular cuticular thickening were visible in D. draco [43]. All of the Dracaena species have no trichomes on leaf lamina [43], but several species have more or less serrulate margins (D. ombet, D. serrulata, and D. cinnabari) or even short thick trichomes (D. jayniana) [43]. The amphistomatic leaf structure of Dracaena species has an isobilateral arrangement of tissues with outer chlorenchyma and a central region with colorless water-storage cells, scattered chlorophyll cells, and vascular bundles [43] (Figure 3a,b). Vascular bundles are collateral and they are surrounded by a well-developed sclerenchymatous sheath $[43,84]$ (Figure 3a,b). Calcium oxalate crystals in the form of raphides are quite abundant in leaves $[43,86]$.

\subsection{Secondary Growth in Stem and Roots}

The representatives of the genus Dracaena belong to a small group of monocots that are characterized by secondary growth in aboveground organs [72,88-90]. Interestingly, Dracaena species have also evolved secondary thickening in their adventitious roots, representing a unique developmental feature across all monocots [72,91]. In both organs, secondary growth is associated with the development of (a) secondary protective tissue, called storied cork, and, (b) secondary vascular tissue that is produced by monocot cambium [72,90] (Figure 3e,g). The development of storied cork is initiated by repeated divisions of meristematic cells situated at the margin of cortex [91,92]. These meristematic cells can hardly be distinguished from the surrounding cortical cells, as they do not form a continuous layer [92]. Its derivatives differentiate as cork cells that are arranged in rows/tiers, more or less regular on the cross-sections.

In contrast to the storied cork, the development of the secondary vascular tissue is a more complex process. The monocot cambium forms a continuous ring of meristematic cells that produce derivative cells mostly centripetally, where they differentiate into the cells forming vascular bundles and the surrounding ground tissue (Figure $3 \mathrm{~g}$ ), while the few cells that are produced in the opposite direction differentiate into cortex cells. The secondary vascular bundles that are developed in Dracaena stems are amphivasal (the central phloem part surrounded by thick-walled tracheids), and can be thus easily distinguished from collateral primary vascular bundles [72] (Figure 3f,g). The two modes of amphivasal bundles formation identified depended on the rate of the monocot cambium activity [93]. These bundles frequently anastomosed with other axial strands, including primary vascular bundles, thereby improving the integration of the stem vasculature [91,94,95]. 

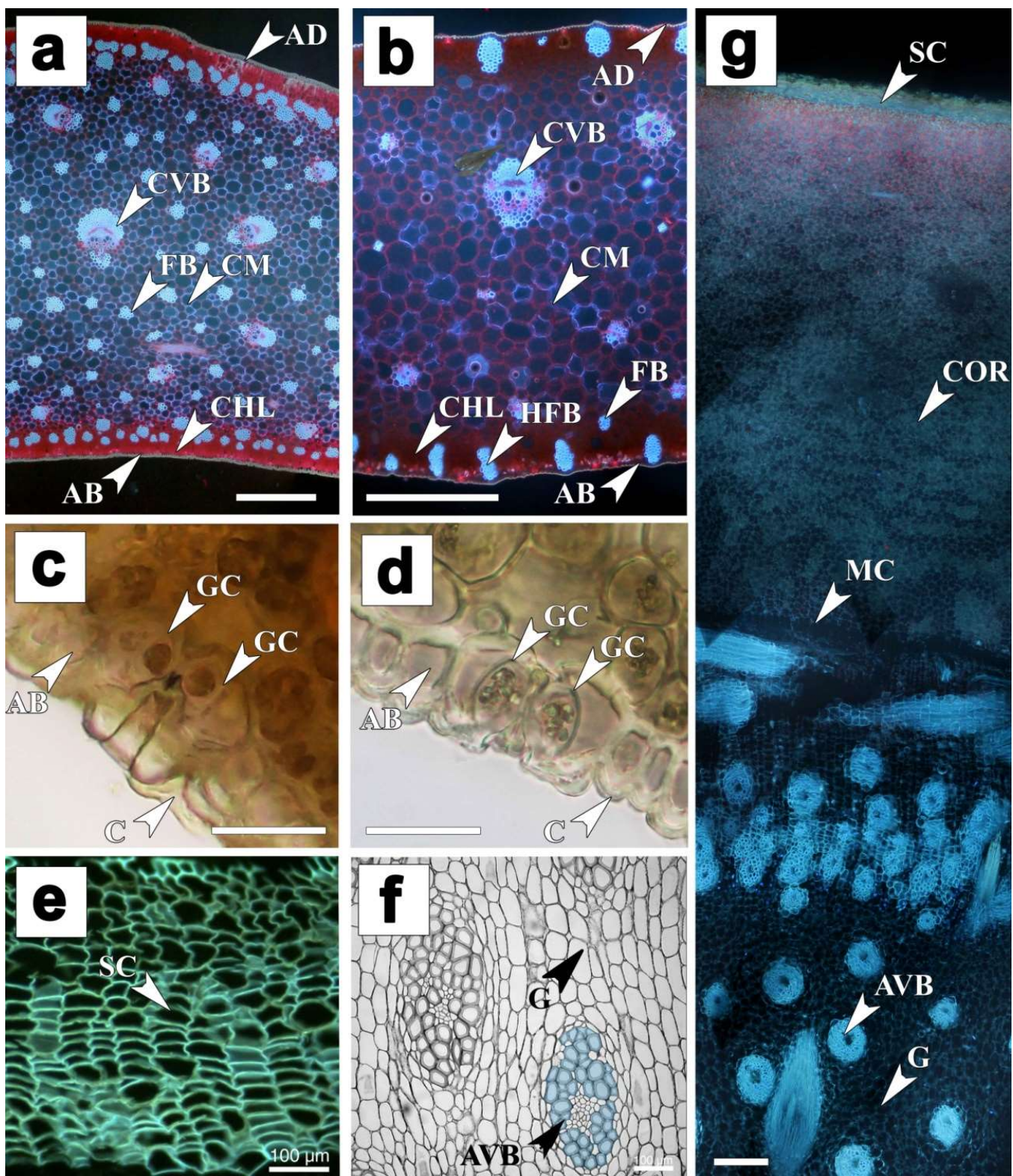

Figure 3. Anatomical details of the leaf and stem of a dragon tree. (a) D. cinnabari, leaf cross-section; (b) D. draco, leaf cross-section; (c) D. cinnabari, sunken stomata; (d) D. draco, bulging stomata; (e) D. draco, detail of storied cork; (f) D. draco, cross-section of secondary tissues with visible amphivasal vascular bundles surrounded with the ground tissue; thick-walled tracheids are marked with blue (g) D. cinnabari, stem cross-section with secondary growth. Abbreviations: $\mathrm{AB}$-abaxial epidermis; $\mathrm{AD}$-adaxial epidermis; AVB-amphivasal vascular bundle; $\mathrm{C}$-cuticle; $\mathrm{CHL}$-chlorenchyma; $\mathrm{CM}$-central mesophyll; COR—cortex; CVB—collateral vascular bundle; FB—fibre bundle; G—ground tissue; GC-guard cells; HFB-hypodermal fibre bundle; MC—monocot cambium; SC—storied cork. Scale bars: (a,b) $500 \mu \mathrm{m}$; (c,d) $30 \mu \mathrm{m}$; (e,f) $100 \mu \mathrm{m}$ and (g) $200 \mu \mathrm{m}$.

During the differentiation of a secondary vascular bundle, tracheids undergo intrusive growth, resulting in up to $40 \times$ greater length as compared to the vascular bundle mother cells [71,95-97]. The intensive elongation of tracheids in the matrix of surrounding cells affects their shape, dimensions, and mutual contact. Therefore, the individual tracheids are far from being perfectly spindle-shaped, like tracheids in conifers, but they become frequently twisted or interwoven with other tracheids and they contain numerous protrusions along their length [95]. The physical proximity of tracheids in 
combination with positional changes within the bundle promotes a high frequency of lateral contact among neighboring tracheids [95]. Nevertheless, these tracheids are rarely connected by their tapering ends, but the end of one tracheid usually overlaps the body of the neighboring one [95]. The adjacent tracheids are interconnected by scalariform or circular bordered pits with slit-like apertures and homogeneous pit membranes [72,95]. The fully differentiated tracheids are relatively wide and long, typically being up to $45 \mu \mathrm{m}$ in diameter and $5 \mathrm{~mm}$ in length, as observed in e.g., D. draco [73,95]. The complexity of the tracheid network, which functions both in transport and mechanical support, seems to have a major impact on the tree-like growth habit of the dragon tree group.

The phloem part of the vascular bundle consists of thin-walled sieve elements and companion cells, which are substantially narrower, shorter, and less numerous than tracheids. No more than six sieve elements have been observed in a typical secondary vascular bundle [98]. The length of these cells usually reflects the length of the cambial initials. The phloem part is not completely isolated from the secondary ground parenchyma by tracheids, but each secondary bundle typically contains sector/s, where the ring of tracheids is interrupted by vascular parenchyma cells [99]. It was proposed that such a structure of amphivasal vascular bundle facilitates the radial transport of assimilates and other compounds between phloem and ground parenchyma [99].

The ground parenchyma tissue represents the major component of the stem (Figure $3 f, g$ ). For example, in the stems of D. cinnabari, the ground parenchyma occupied $77 \%$ of total cross-sectional area [73]. Surprisingly, the functional significance of the ground tissue in dragon trees is relatively poorly understood. There are no special secondary radial tissues providing radial symplastic transport as ray parenchyma in coniferous or dicotyledonous trees in arborescent monocots with secondary growth $[100,101]$. However, the parenchyma cells in the secondary ground tissue are produced in regular radial files (in contrast to the primary ground tissue that shows no such pattern) [72] and those ground parenchyma cells are typically densely interconnected by simple pits that are present in their cell walls [86]. Therefore, it can be anticipated that the ground parenchyma might serve as an extra-fascicular symplastic transport pathway [84,99]. With respect to the great proportions of the ground parenchyma in stems, this tissue apparently represents the main reservoir of soluble carbohydrates and water, and it can be considered as one of the important adaptive traits underlying the ability of some Dracaena species (e.g., D. draco) to survive long-term drought episodes [86,99]. Furthermore, the cell walls of ontogenetically older ground parenchyma (typically parenchyma cells surrounding vascular bundles) become more lignified, which might strengthen integrity of vascular bundles and further improve the mechanical stability of the stem [99].

In Dracaena roots, the secondary growth typically starts in ontogenetically older root regions with well-developed primary tissues and lignified endodermis [98]. The monocot cambium in roots typically produces secondary tissues between endodermis and the primary cortex [71,91]. The proportions of vascular bundles and ground parenchyma in roots appear to be similar to stems [73]. However, in contrast to vesselless stems, the primary xylem in roots is composed of wide vessels, while the secondary vascular bundles only contain tracheids [72]. The tracheids that are present in secondary vascular bundles are wide in diameter, which might help to compensate their higher flow resistance as compared to vessels [72]. No direct connection exists between vessels in primary vascular bundles in roots and tracheids in stems since the stems in dragon trees do not contain vessels. Therefore, synchronized production of secondary vascular bundles containing wide tracheids in roots and stems appears to be a reasonable mechanism, allowing for the connection of both organs and the maximization of the total transport capacity [72]. Similar to soil roots, aerial roots, which proliferate from aboveground organs of dragon trees, are also capable of secondary growth [74]. Although we do not know much about the anatomy or functional significance of these structures, it appears that the structure of secondary vascular bundles in the aerial roots of $D$. draco resembles the structure of secondary bundles in stems [74]. 


\subsection{Dracaena Resin Secretion}

Dragon trees produce red resin named dragon's blood. It is secreted in response to external stimuli, i.e., after stem, branch, or leaf wounding caused by both biotic and/or abiotic stress factors, like insect infestation or mechanical damage. Red resin production and accumulation can be also stimulated by fungal inoculation e.g., Fusarium proliferatum, F. oxysporum in stem of D. cochinchinensis [68,102], Gibberella sp., Septoria sp. in stem of D. cambodiana [103], and Colletotrichum gloeosporioide in the leaves of D. cochinchinensis [104]. The resin can also be induced chemically [105]. Dragon's blood does not appear directly after the wound, the process of its formation takes time [106]. Eventually, the resin might be in the form of tear-like drops or chips [107] (Figure 2b,c). It coats the place of injury, protecting the plant from the spread of pathogens through the wound, thus it is a dragon tree defense mechanism [108,109].

No special secretory structures for dragon's blood production and secretion have been identified in wounded and inoculated stems of dragon trees [103,106]. However, data on the anatomical origin of red resin in the stem of dragon tree are not consistent. González et al. [110] indicated the bark, while Cui et al. [103] and Wang et al. [68] the xylem. In turn, Jura-Morawiec and Tulik [106] emphasized that resin secretion is possible by living cells only, and indicated the ground parenchyma of both primary and secondary origin, and the cells of cortex containing polyphenolic-like inclusions as resin sources. Wang et al. [68] mentioned plant age and keeping the wound moist with regard to the factors that may be relevant to the secretion of dragon's blood.

\section{Ontogenetic Cycle and Its Lifespan}

Generally, the ontogenetic cycle of woody plants consists of two phases: vegetative, when the tree is not yet blooming, and generative, when the tree is capable of reproduction by seeds. Both phases can be divided into several stages. Some progress has been made in identifying particular ontogenetic stages only within D. cinnabari and D. draco. Habrová and Maděra [111] divided the ontogeny of D. cinnabari into three main stages. In the first, the plant creates no trunk, just a single rosette with increasing numbers of elongating leaves. After a number of years depending on site conditions, the plant develops a stem with a single rosette at the top. In the last stage, the crown branches after first flowering and gradually forms the distinctive, umbrella-shaped crown of the adult tree.

Attorre et al. [18] used more details to divide the third stage in two, being represented by a plant with more than one rosette, as well as a crown of diameter less than $2.5 \mathrm{~m}$, and in the next (fourth) stage the plant has a crown larger than $2.5 \mathrm{~m}$.

The first two stages belong to the vegetative phase. Starting with the first flowering events the dichotomously branching crown is created [112]. Consequently, the stages with more than one leaf rosette belong to the generative phase [113] (see Figure $4 \mathrm{a}-\mathrm{h}$ ).

Maděra et al., [113] distinguished the following juvenile stages of $D$. cinnabari vegetative phase (Table 1, Figure 4a-d): 
Table 1. Description of juvenile stages of D. cinnabari (according to Madera et al., [113]).

\begin{tabular}{|c|c|}
\hline Stage & Description \\
\hline Seedling & $\begin{array}{l}\text { This stage is characterized by height increase being realized through leaf } \\
\text { elongation. The completion of leaf elongation defines the end of this stage. In } \\
\text { natural condition this stage lasts minimally five years, probably more. }\end{array}$ \\
\hline Early juvenile stage & $\begin{array}{c}\text { The number of leaves increases, and height growth is realized by addition of new } \\
\text { leaves to the rosette. The appearance of stem formation defines the end of this } \\
\text { stage. this stage typically lasts } 5 \text { to } 10 \text { years, but can be as short as } 3 \text { years and as } \\
\text { long as } 15 \text { years }\end{array}$ \\
\hline Medium juvenile stage & $\begin{array}{l}\text { The onset of this stage is defined by the first appearance of the stem, and height } \\
\text { increase is realized by stem growth. The end of this stage is defined when the stem } \\
\text { height reaches } 1.3 \mathrm{~m} \text {. The stem diameter strongly depends on the number of leaves, } \\
\text { thus the future stem diameter of adult trees is determined by the vitality of the } \\
\text { plant in the early and medium juvenile stages. The end of this stage occurs when } \\
\text { the tree is about } 100 \text { years. }\end{array}$ \\
\hline Late juvenile stage & $\begin{array}{l}\text { The stem height is more than } 1.3 \mathrm{~m} \text { and its end is defined by the onset of first } \\
\text { flowering. This stage lasts between } 100 \text { and } 150 \text { or more years. }\end{array}$ \\
\hline
\end{tabular}

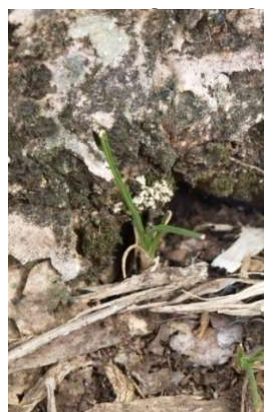

(a)

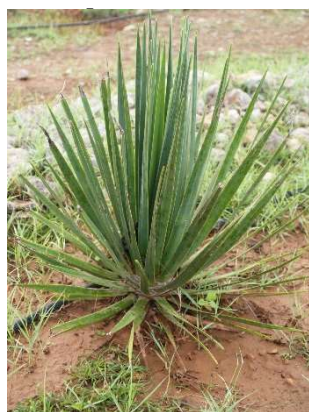

(b)

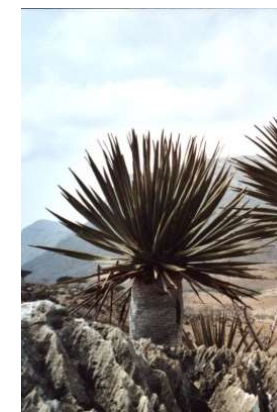

(c)

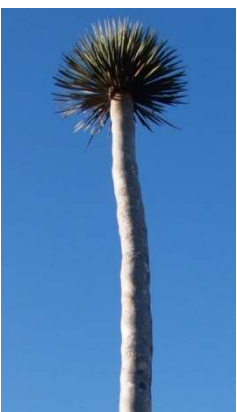

(d)

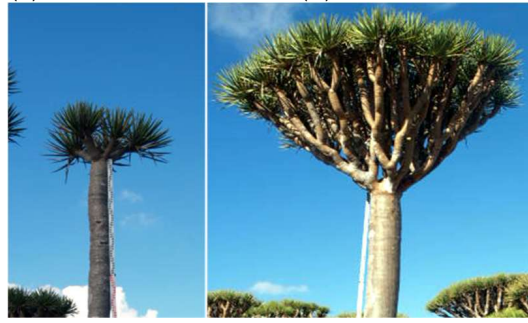

(f)

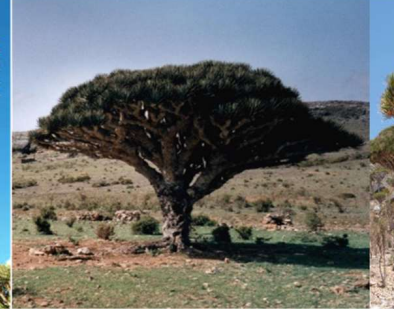

(g)

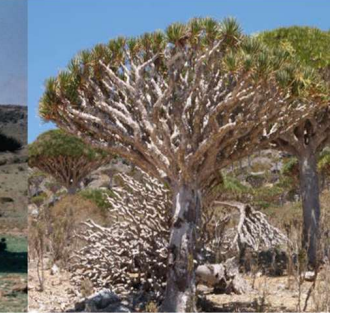

(h)

Figure 4. The vegetative phase (upper line of pictures) consists of seedling (a), early juvenile (b), medium juvenile (c) and late juvenile (d) stages. The generative phase (lower line of pictures) consists of early adult (e), fully adult (f), senescence (g) and senility (h) stages.

Hubálková et al. [114] described the first two years of D. cinnabari plants' growth in greenhouse conditions, with average seedling height of $24.9 \mathrm{~cm}$ and leaf number 8-16 at the end of this period. The average annual plant height increment of $D$. cinnabari planted in situ without irrigation in the early juvenile stage was only $2.65 \mathrm{~cm}$ [113]. This growth parameter data showed that $D$. cinnabari is a very slowly growing tree species.

Probably, D. draco is a faster growing species, as Krawczyszyn and Krawczyszyn [76] documented irrigated and fertilized 19-year-old plants in the garden of Hoppers Crossing (Australia), reaching a mean annual height increment of $26 \mathrm{~cm}$. Additionally, irrigation 3.43 times accelerated the mean annual plant height increment of eight years old seedlings of $D$. cinnabari planted in situ (from 2.65 to $9.1 \mathrm{~cm} / \mathrm{yr}$ ) [113]. Adolt and Pavliš [14] estimated the mean stem height annual increment of D. cinnabari in medium and late juvenile stages of trees cultivated in home gardens on Soqotra at $10 \mathrm{~cm}$ per year. Byström [79] mentioned the height and age of five specimens of D. draco subsp. caboverdeana $(11 \mathrm{~m}$ in 
80 years and $7 \mathrm{~m}$ in 57 years), which means that the mean annual height increment was $12.3-13.8 \mathrm{~cm}$. Mature dragon trees reach a height up to $20 \mathrm{~m}$ (Table 2).

Table 2. Height of the individual species of the dragon trees.

\begin{tabular}{cc}
\hline Species & Height [m] \\
\hline Dracaena draco subsp. ajgal & $20[4]$ \\
Dracaena draco subsp. draco & $12[4], 21[115], 22[116]$ \\
Dracaena draco subsp. caboverdeana & $8[7]$ \\
Dracaena tamaranae & $10[4]$ \\
Dracaena cinnabari & $10[4], 12[111]$ \\
Dracaena ombet subsp. schizantha & $9[4]$ \\
Dracaena ombet subsp. ombet & $8[4]$ \\
Dracaena serrulata & $8[4]$ \\
Dracaena americana & $10-12(18)[12]$ \\
Dracaena jayniana & $5-8[9]$ \\
Dracaena kaweesakii & $3-6(12)[10]$ \\
Dracaena cambodiana & $3-4(10)[11]$ \\
\hline
\end{tabular}

Regarding radial increment, only data from repeated measurements of a few individual trees of $D$. draco were published [115-117]. The annual increment in stem diameter varied from 0.2 to $1.13 \mathrm{~cm}$ for large, old trees [116,117]. Symon [115] mentioned that the annual increment in stem diameter of younger specimens planted in Australia (16-45 years old) varied from 1.15 to $2.0 \mathrm{~cm}$. Byström [79] published data from Brava Island (Cape Verde Islands) for five specimens of D. draco subsp. caboverdeana 57 and 80 years old, with an annual increment in stem diameter of 1.05-1.25 $\mathrm{cm}$. Repeated measurement of the radial stem increment can bring many mistakes, one of the most important seems to be a massive growth of the aerial roots of $D$. draco described by Krawczyszyn and Krawczyszyn [74], which can substantially enlarge the size of stem.

Knowledge regarding the age of dragon trees is very important for conservation management of what are mostly endangered species [14]. First age estimations were published for D. draco by Humboldt [118], Christ [119], and Schenck [120]. These authors all overestimated the age of a huge tree with $15 \mathrm{~m}$ stem girth from Orotava (Tenerife) by several thousand years. The first person to use the relationship between the duration of flowering period and characteristic branching for age estimation of D. draco, was Pütter [117]. He concluded that none of the living specimens were older than 300 years, except the tree from Orotava, which was estimated to be 575 years old. The duration of the flowering period, according to Pütter [117], varied from 14.2 to 23.3 years. Mägdefrau [116] obtained similar results by repeated measurements of the same trees as Pütter, comparing not only the number of flowering periods with a duration ranging from 11 to 17 years, but also the radial increment of the stem. The oldest tree in Icod (Tenerife) was 365 years. Similarly, Symon [115] compared the increment of cultivated specimens of D. draco in Australia and the precise date of its planting, estimating the duration of the flowering period to be between nine to 14 years. Zheng et al. [11] inferred from stem diameter, which ranged from 50 to $120 \mathrm{~cm}$, that the individuals of D. cambodiana are several hundred years old. All these observations were only done for a few of the mostly largest trees. The low number of measured trees and unbalanced representation of different age classes does not allow for any statistical analysis or modelling.

More recently, Adolt and Pavliš [14] published a method of crown age estimation of $D$. cinnabari that Adolt et al. improved upon later [112]. This approach was based on the linear relationship between duration of flowering period and number of branch sections [14] with each branch section corresponding to one flowering period. The mean duration of the flowering period of an individual crown apex of 18.7 years (min. 13.7 and max. 29.6) was counted according to the percentage of leaf rosettes with inflorescence from all the circumferential leaf rosettes of the crown. Adolt et al. [112] published an improved method of crown age estimation while using logistic regression. The time between flowering events decreased from 28 years between the first and second event to 10 years between the 25th and 26th event in highland localities (700 $\mathrm{m}$ a.s.1.) and differs substantially in montane localities (1450 $\mathrm{m}$ a.s.l.), where the flowering interval has a constant value of 6.5 years. The average age 
of a crown with 30 branch orders of D. cinnabari tree is, according to the highland model, 500 years, as compared to the mountain model of 193 years. This method cannot be used for the age estimation of juvenile trees that are not yet blooming.

The duration of juvenile stages that were published by Maděra et al. [113] for D. cinnabari can last in natural conditions more than one or two hundred years (Table 1). The vegetative phase of 15 irrigated and fertilized D. draco trees planted in a garden (Hoppers Crossing, Australia) lasts between nin and 19 years, a similar time span to the 9-11 years mentioned by Symon [115], and at least ten times shorter than was estimated for D. cinnabari [113], according to results published by Krawczyszyn and Krawczyszyn [76]. The age of first flowering was estimated for a few trees of $D$. draco growing on Canary Islands as 25-80 years by Mägdefrau [116] and for D. draco subsp. caboverdeana as 10-25 years by Byström [79].

\section{Water Relations}

In this section, we give an overview of water relation studies on D. cinnabari and D. draco, two famous representatives of the dragon tree group. The research was based on analyses of sap flow response of in-situ measured adult trees to wide-scale variations in environmental conditions and to several treatments of young plants growing $e x$-situ. The same sap flow method, namely the Heat Field Deformation (HFD) method [121-123] was used, enabling the exploration of radial sap flow variations, high time resolution, and bidirectional flow rates.

Both species demonstrate low sap flow rates that agree with expected values, as Dracaena species have only tracheids in the stems and leaves [72]. The succulent characteristics, high leaf mass per area, thick cuticles, and the narrowness of the leaves (although at different scales) that were observed in both species [84] indicate their high resistance to high transpiration rates. However, transpiration might substantially and abruptly increase after dry soil watering, as was confirmed by gravimetrical measurements of the irrigated potted Dracaena species (unpublished data). The huge internal storage of succulent woody organs is responsible for a time lag that might exist between actual transpiration and sap flow. Sap flow thus reflects rates of internal storage use and refilling, both of which are dependent on current and previous transpiration rates-driven by atmosphere and soil moisture. For example, sap flow might sharply increase, even at night under low evaporative demands when the dry soil has been watered (unpublished data) or after intensive rain events following drought [124]. In this case, high night sap flow rates reflect the fast refilling of internal storage desiccated by drought, and do not designate high transpiration. For adult trees, the position of the sensor installation is crucial, as it manipulates the percentage of internal storage included in transpiration, which is first used presumably from internal reserves [124].

The similarity of overall tree architecture and crown type of both Dracaena species might contribute to the ability of these plants to route water intercepted by leaves through leaf axils to the succulent woody organs for storage and further use. This ability of D. draco and D. cinnabari was demonstrated by watering the leaf axils of young plants under different edaphic and climatic conditions in greenhouse experiments [125].

Partial stem incision treatment, was conducted on young plants of both Dracaena species in order to understand the influence of stem wounding often observed in Dracaena species in-situ due to the harvesting of the famous resin [126]. This experiment demonstrated the capability of Dracaena species to bypass axial water flow by lateral transport in case of stem wounding [127]. The ability of arborescent monocots to conduct water in any direction through an extremely complex three-dimensional network of vascular bundles connected to each other and to the cells of ground tissues was also found in adult D. draco $[126,128]$ and D. cinnabari [126].

Negative sap flow at night was consistently recorded in young Dracaena species, even in the conditions of wet soil and zero vapour pressure deficit (VPD) [84]. Daily sap flow was identical in all stem radial layers of a young $D$. draco plant, whereas it was slightly higher in the inner stem part of D. cinnabari plant [84]. Radial sap flow variability of adult trees is extremely complicated and it 
significantly depends on internal storage availability, its usage during the daily circle, and the level of drought stress [126-128]. It is possible to determine the efficiency of different stem parts in the water transport of these arborescent monocots while using the ability of the multi-point HFD sensor to follow the radial changes of flow rates.

Although the majority of functional traits were similar for both Dracaena species, a certain difference in water relations was also found-based on species adaptation to different environments-in arid-tropical (for D. cinnabari) and subtropical (Mediterranean) (for D. draco) climatological zones. A comparable $e x$-situ study on young $D$. cinnabari and D. draco plants demonstrates that an adaptive evolution due to contrasting environments in their habitats on two geographical boundaries of North Africa has resulted in a different anatomical leaf structure of both the more remote Dracaena species (see Section 3.2.). The anatomical peculiarities of the leaves in both species are reflected in differences in their functional traits. It was found that a different daily relationship emerged between the VPD and sap flow in Dracaena species, with a clockwise or lack of a hysteresis loop for D. draco and a counter-clockwise hysteresis loop for D. cinnabari [84]. The more xeric morpho-anatomical structure of $D$. cinnabari leaves with their thicker level of wax and deeply sunken stomata $[4,84,87]$ evidently requires higher driving forces to start transpiration, and it provides a better water-saving strategy with a shorter daily transpiration cycle in comparison with $D$. draco plants.

According to the sap flow records in all of the sample plants, Dracaena species do not develop facultative Crassulacean Acid Metabolism (CAM) photosynthesis, as was reported by Brown and Mies [23] for D. cinnabari that were exposed to increasing levels of drought conditions. Clear circadian rhythms with higher daily sap flow rates typical for C3 plants were recorded in the stems of all measured Dracaena species. However, bearing in mind the preliminary nature of our study, related, in part, to the limited number of analyzed specimens, specially oriented research will have to be undertaken in the future to confirm the findings of Brown and Mies [23] as regards CAM in D. cinnabari. This also applies to other physiological studies, e.g., photosynthesis, metabolism, nitrogen assimilation, mineral nutrition, etc. has been poorly learned to date. Carlquist [72] remarked that the lack of studies on monocot functionality is probably due to the lack of commercial importance of arborescent monocots and their remoteness from major academic institutions. In this section, we have shown a certain progress in water relation studies of Dracaena species. The other basic physiological studies still wait for future intensive research.

\section{Dracaena Resin and Ethnobotanical Use of Dragon Trees}

\subsection{Chemical Diversity of Dracaena Resins}

Dragon's blood is the name given to a deep red exudate obtained from different species of five distinct plant genera: Croton, Dracaena, Daemonorops, Pterocarpus, and Calamus [69,107,129]. However, the original source of dragon's blood is supposed to be D. cinnabari from the Indian Ocean island of Soqotra [130]. It is classified as a resin or latex, depending on its manner of secretion and its chemical composition, and these are species specific $[109,131]$. From ancient times it was highly valued by many cultures for its traditional medicinal properties $[132,133]$. Due to the belief that it is blood from a dragon, it was used also in magic rituals and alchemy [134]. The chemical composition of resin in Dracaena species is very complex. Numerous phytochemical studies of resins from the Dracaena species resulted in the isolation and subsequent identification of sterols [135-138], steroidal saponins [110,138-141], lignans [138], and terpenoids [131,135,142-144], flavonoids (recently reviewed by Sun et al. [129], bioflavonoids [145,146], carotenoids [109,138], and aromatic compounds [107,147-151].

\subsection{Bioactive Properties of Dracaena Resins}

Dragon's blood was used for its antiseptic properties from ancient times and the resins are still a natural remedy in some cultures today [130]. Polyphenols are bioactive components of Dracaena resins and they are responsible for broad pharmacological activities, such as hemostatic, antidiarrheic, 
antiulcer [152], antimicrobial [153], antiviral [154], antitumor and cytostatic [155], anti-inflammatory and analgesic [156], antioxidative [157], hypolipidemic, and hypoglycemic [107,129] (reviewed by Gupta et al. [107] and Sun et al. [129]). Furthermore, modern pharmacological evaluations revealed the bi-directional regulatory effects of the polyphenolic extracts of Dracaena resin on hemorheology and cardiovascular [158] and cerebrovascular systems (reviewed by Sun et al. [129]).

\subsection{Historical Records of Dracaena Resins}

The historical text of Pliny the Elder's Historia Naturalis (c. first century AD) goes to great lengths to explain the perpetual war between elephants and dragons and how dragon's blood could be collected from the place where these two beasts fought and died together [159]. However, the first reference to the actual origins of dragon's blood comes from the Periplus Maris Erythraei (mid-first century BC), which mentions that Arab, Indian, and Greek settlers were sailing to Soqotra to trade in tortoise shell, aloes, and Indian cinnabar [160]. According to Pliny et al. [159], cinnabar is the name given to dragon's blood by the Indians. Presumably the term Indian cinnabar, used to describe the dragon's blood resin from Soqotra, was due to it having been mostly distributed by Indian merchants or on Indian ships. This would certainly seem to be corroborated by the epigraphic evidence in Hoq cave on Soqotra, in which the text and symbols of Indian merchants and sailors are, by far, the most numerous [161]. Unfortunately, the historical texts do not provide any certainly as to the quantities of dragon's blood resin that were being traded, yet it appears that it was in high demand by apothecaries, alchemists, and painters. A Fourier-transform Raman Spectroscopic study of dragon's blood resins from a number of geographical locations found that the original source of this resin in antiquity was from the D. cinnabari of Soqotra [130]. This would certainly seem to indicate that Soqotra was not only a primary source of dragon's blood in antiquity, but that it was being intensively harvested. Whilst the trade in dragon's blood resin continued throughout the medieval period, there were an increasing number of alternatives from different geographical locations, such as the Canary Islands and the East Indies [130]. Notwithstanding the availability of these alternative sources, the dragon's blood resin of Soqotra was still highly sought after and continues to be mentioned in Arabic and Chinese sources [162-165]. This demand continues into the seventeenth century, with the ships of the East India Company reportedly having carried out a small trade in aloes and dragon's blood $[166,167]$. The importance of this trade locally is reflected in a nineteenth century account, which mentions that the Sultan not only controlled much of the trade, but also derived his third highest source of revenue from dragon's blood resin, after ghee and aloes [168]. By the twentieth century, however, the trade in dragon's blood from Soqotra reportedly collapsed, due to the reduced demand that drove prices down to such a level that harvesting was no longer profitable [169].

\subsection{The Management and Harvesting of Dracaena cinnabari Resin}

Whilst the trade in dragon's blood is likely to have formed an important part of Soqotra's economy for several centuries, little is known regarding how it was managed or harvested. Indeed, the first record of the harvesting of dragon's blood resin is found in the journals of Lieutenant Wellsted, who visited the island in the mid nineteenth century. According to his report, dragon's blood resin exudes spontaneously from the tree and the Bedouin collects it throughout the year [170]. Several years later, when Captain Hunter visited the island he noted that, contrary to Wellsted, the Bedouin would incise and scrape a portion of bark off the dragon's blood tree, leaving a space that would fill with resin in 2-3 weeks, and that would be collected in the end of April [168]. Importantly, he also mentions how the island was divided into lots and leased to the Bedouin tribes. The tracts of land containing dragon's blood trees were said to have been divided between the Sultan, who would keep one portion of land, and the Bedouin, to whom the remainder would be leased [168]. This division of the land is particularly interesting, in that throughout Soqotra there are a series of walls, the function of which has been connected by several archaeologists [171-177] with dragon's blood management and harvesting. They hypothesize that the walling of the interior is likely to date to a period when Soqotra was a major 
supplier of aloe, incense, and dragon's blood [176]. Recent investigations $[177,178]$ of wall systems on Soqotra recognize its multifunctional use, however they do not exclude connection with dragon's blood management.

The harvesting (Figure 2c) and processing of dragon's blood by local inhabitants on Soqotra has been preserved in its traditional ancient form to this day [27]. There is no similar record in scientific literature for other species of dragon trees, although we can assume, especially in East Asia, that similar methods could be used for dragon's blood harvesting of D. cochinchinensis and D. cambodiana, where is broadly used in traditional ethnomedicine $[11,68,107,129]$.

\subsection{Other Uses of Dracena Species}

Dragon trees are famous worldwide for their resin, which has been used from ancient times in ethno-medicine, cosmetics, as a decorative paint or marker, as a glue and a dye for leather $[27,179]$ (see Sections 6.1-6.4). On Soqotra, the harvested resin of D. cinnabari is sorted into different grades tha are used for different purposes, both the high-value fresh droplets and the processed resin-bearing bark [27].

However, people living where dragon trees grow have used other parts of these plants. Miller and Morris published the best description of the ethnobotanical use of a dragon tree (D. cinnabari) [27] (see Černý et al. [180] for a discussion on Soqotra having been inhabited since 6000 BP).

Leaves, inflorescences, and fruits are used as fodder for livestock in the Arabian Peninsula, Soqotra, and Africa $[17,27,181]$. Leaves of $D$. serrulata in Oman and of D. cinnabari on Soqotra are used to make cordage [27], and leaves of D. ombet in Ethiopia to weave mats [182]. In the drier areas of Soqotra, there is a tradition that starving people would collect the red berries of $D$. cinnabari, boil, and eat them, as in Ethiopia, where the mature fruits of $D$. ombet are eaten by very hungry people [22]. In Oman, the growing buds of $D$. serrulata and the hearts of rosettes of leaflets were eaten [183].

The hollow trunk of both D. cinnabari on Soqotra and D. serrulata on the mainland opposite were used to make drums of varying sizes [27]. In Saudi Arabia, Yemen, Oman, and Ethiopia the hollow trunk is used as a beehive $[17,181]$, and on Soqotra and in Ethiopia, hollowed chunks of a branch are turned into bowls and containers [27,181]. The branches were cut in half along their length and used as guttering for the stone houses of the Soqotra mountains [27]. Dracaena flowers are an important honeybee forage [27]. On Soqotra, dead wood was burned as an insecticide and pieces of shed bark or the fibrous interior of dead branches were used for firing and colouring pottery [27]. In Ethiopia the branches and stem of D. ellenbeckiana are the main source for farming tools [182].

The dead wood of Dracaena and the dried fibrous material from inside the trunk can be used as fuel. Slices of resin-bearing bark from $D$. cinnabari made a good torch, and the logs were burned at night for their bright light. Dragon trees were used in construction, and the leaflets of $D$. cinnabari were used as roofing material [27].

\section{Ecology of Plant Communities with Dragon Trees}

Dracaena species belonging to the dragon tree group can be divided into three groups that are based on the geography and broader environmental conditions: the Macaronesian group (D. draco and D. tamaranae), the northeast African/Arabian group (D. cinnabari, D. serrulata, D. ombet, and D. ellenbeckiana), and the southeast Asian group (D. cambodiana, D. cochinchinensis, D. jayniana, D. kaweesakii, and D. yuccifolia). Although separated geographically, the groups share several characteristics and are biogeographically related $[4,9,43,184]$.

The species of the Macaronesian group grow on the volcanic islands of Macaronesia and in the adjacent area of southwest Morocco (see Section 2). The area of Macaronesia encompasses several Atlantic archipelagos and a part of northwest African mainland [185], and spans over different climate types [186,187]. Generally, in Macaronesia, temperature increases and precipitation decreases towards the equator. The broad climate of each site is further modified by local conditions, mainly by orography, exposition, distance from the sea, and orientation to prevailing northeastern trade winds. Along with 
the differences, the habitats of Macaronesian dragon trees are largely similar in their environment, biogeography, and plant communities [4,188]. The dragon trees in the area, likewise the species from the other two groups, prefer sites that are affected by fog formation (but see D. tamaranae). Here, the umbrella-shaped crowns with their dense leaf-rosettes intercept droplets of water from fog [189], which then drips and flows down the trees, enriching the soil with moisture.

On Madeira, the wild population of D. draco subsp. draco was mainly found on sea-facing cliffs and as an element of thermo-sclerophyllous zones between sea-level and $200 \mathrm{~m}$ a.s.1. [52] in the vegetation of the class Rhamno crenulatae-Oleetea cerasiformis [190]. Similarly, on Tenerife, D. draco occurs in thermo-sclerophyllous vegetation of the same class, namely in the alliance Mayteno canariensis-Juniperion canariensis, between 100 and $600 \mathrm{~m}$ a.s.l., where the annual mean rainfall ranges between 200 and $400 \mathrm{~mm}$ [4]. On Gran Canaria, D. draco grows in similar habitats to those on Tenerife, but only in the northeastern part of the island that is by the moisture-bearing trade winds [16].

On the Cape Verde Islands, the climate with natural populations of D. draco subsp. caboverdeana is classified as tropical xeric and tropical pluviseasonal [7]. The tree grows in a wide range of elevation from $50 \mathrm{~m}$ a.s.l. to $1400 \mathrm{~m}$ a.s.l. on the slopes that are exposed to the northeastern trade winds [79], which bring the majority of moisture to the archipelago [191]. The characteristic community with D. draco subsp. caboverdeana is deciduous micro-woodland climactic savanna of the alliance Fico gnaphalocarpae-Acacion caboverdeanae, which was typically structured by short trees including the Dracaena. However, over the last centuries the demand for wood, grazing and agriculture has reduced the tree cover substantially [192].

$D$. draco subsp. ajgal, which is the most abundant $D$. draco subspecies, is native to the western Anti-Atlas Mountains in Morocco, where it is restricted to rocky and steep cliffs of an isolated basin between two mountain ranges of the Jbel Imzi area [8]. The elevation of the locality ranges from 250 $\mathrm{m}$ a.s.1. to $1540 \mathrm{~m}$ a.s.l. and the climate is characterized as infra-mediterranean in lower elevations to thermo-mediterranean in higher elevations [8]. The mean annual temperature is estimated to be around $20^{\circ} \mathrm{C}$ and the annual rainfall to be at least $500 \mathrm{~mm}$ with additional moisture from frequent fogs [8]. The communities with D. draco subsp. ajgal were classified into the association Davallio canariensis-Dracaenetum ajgal [8].

D. tamaranae is a cliff-dwelling species restricted to Gran Canaria island, where it grows on inaccessible slopes between 342 and $1270 \mathrm{~m}$ a.s.l. in the southwestern region [16]. Although the sites with $D$. tamaranae tend to be shady and humid, they are more xeric and hotter when compared with sites inhabited by D. draco [4]. The average annual rainfall in the species altitudinal range is between 200 and $400 \mathrm{~mm}$ and the leeward southwestern region of Gran Canaria is not influenced by moisture-bearing trade winds [16]. Rains in the area tend to be torrential and very irregular, usually occuring between November and February, making the rest of the year a dry period [16]. The average annual temperature does not reach $21{ }^{\circ} \mathrm{C}$; however, the monthly averages exceed $25{ }^{\circ} \mathrm{C}$ in some summer months and they rarely fall below $15^{\circ} \mathrm{C}$ in the winter [16]. This arid and semiarid climate determines a pronounced xerophytic character of $D$. tamaranae communities that belong to the class Rhamno crenulatae-Oleetea cerasiformis, and, to a lesser extent, to Kleinio-Euphorbietea canariensis (at lower elevations) and Chamaecytiso-Pinetea canariensis (at higher elevations) $[4,16]$.

The species of the northeast African/Arabian group are found in the arid and semiarid vegetation of mountains and escarpments along the Red Sea and Gulf of Aden and on Soqotra Island. The dragon trees grow in higher elevations and are strongly dependent on orographic fog formation due to the high aridity, which brings additional moisture into the environment. The horizontal precipitation constitutes an important input of water which may exceed the rainfall [31] and localities with the dragon trees are commonly found in areas known as mist oases [193].

Brown and Mies summarized the ecology and plant composition of communities with the Soqotran endemic D. cinnabari [23]. The species is confined to areas subject to the formation of the monsoon mists and clouds, mostly to limestone plateaus and mountains, where the tree profits from its ability to intercept horizontal precipitation [189]. The rocky limestone plateaus are located between 400 
and $700 \mathrm{~m}$ a.s.l. and the D. cinnabari grows here as an emergent in open semi-evergreen Buxanthus pedicellatus-Dracaena cinnabari woodland. The montane and high-montane vegetation with $D$. cinnabari is found on limestone foothills and granite peaks above $700 \mathrm{~m}$ a.s.l., where the temperature drops during the late afternoon and evening leads to the regular formation of clouds. The interception of horizontal precipitation from clouds and monsoon mist together with dewfall substantially enhance the available moisture leading to the formation of lush vegetation where dragon trees grow as scattered emergents overlooking a dense species-rich shrub layer [194-196]. The findings by Rejžek et al. [28] indicate that $D$. cinnabari acts as an ecosystem engineer, i.e., a key species that alters the abiotic environment, controls the availability of resources, and facilitates the growth of other species.

D. serrulata is found in areas with Acacia-Commiphora bushland in sea-facing mountains, including their inner regions, along the southwestern edge of the Arabian Peninsula [58]. The average annual rainfall in areas with D. serrulata is approximately $200 \mathrm{~mm}$ [4].

D. ombet subsp. ombet inhabits the sea-facing mountains along the Red Sea and north-ethiopian escarpment, mostly in areas that are affected by the mists that come with the winds. On the north edge of its distribution (see Section 2) it grows in desertic igneous mountains between 450 and $950 \mathrm{~m}$ a.s.l. with $50 \mathrm{~mm}$ of annual rainfall and with up to $400 \mathrm{~mm}$ of additional water per year from mist and cloud [20]. It is mostly found growing as isolated individuals or in small groves on steep rocky slopes and cliffs [197]. In the south, along the north-ethiopian escarpment, D. ombet subsp. ombet thrives in higher altitudes (1400-1800 m a.s.1.), in the transition zone between Afromontane vegetation and Acacia-Commiphora bushland, and forms Dracaena ombet-Acacia etbaica community [198].

D. ombet subsp. schizantha is part of dry single-dominant Afromontane Juniperus and Juniperus-Olea forest in the east-ethiopian escarpment where it grows, especially along the forest edges [61]. Further east, it grows in Buxanthus pedicellatus-Acokanthera schimperi bushland and in Rhigozum somalense bushland [61].

D. ellenbeckiana generally grows on rocky slopes in evergreen and semi-evergreen bushlands or open dry woodlands in elevations between 1000 and $2100 \mathrm{~m}$ a.s.l. [61,199]. In Ethiopia, it is known from the transitional vegetation between dry Afromontane forest (Juniperus and Juniperus-Olea forest) and East African evergreen bushland, from typical East African evergreen bushland, and it is transgressing into Acacia-Commiphora deciduous bushland [61,200,201]; altitudinal range 1000-1500 m a.s.1.; and, mean annual rainfall range 300-1000 $\mathrm{mm}$.

The southeast Asian Dracaena species belonging into the dragon tree group grow in tropical or subtropical areas with higher rainfall than the previous groups, but they are usually associated with cliffs and the tops of limestone rocks in karstic landscapes [9,10,202,203], where water availability is reduced due to relief and edaphic constraints [204].

D. cambodiana is usually found in escarpments of island-like limestone mountains [49]. However, it has also been documented growing on granite along the coast with low rainfall, dry heat, and soil with weak water storage capacity as well as along streams in the mountains far from the sea [203], which suggests that $D$. cambodiana can grow in ecologically diverse habitats.

D. cochinchinensis is a species of tropical seasonal evergreen and semi-evergreen moist forests, where it grows on limestone slopes in higher elevation [202]. It grows in environment where seasonal dryness is partially compensated by dense fog and low temperatures during the dry season [202].

D. jayniana is a species of highly seasonal deciduous vegetation of limestone karst and it is usually found on hilltops rather than on steep cliffs; it grows in elevations between 300 and $500 \mathrm{~m}$ a.s.1. [9]. D. kaweesakii is a species of limestone rock and it grows between 550 and $2000 \mathrm{~m}$ a.s.1. [10]. 


\section{Populations, Threat, Nature Conservation}

\subsection{Population Size, Abundance}

Basic information regarding the distribution of individual species (and subspecies) has been published and is mentioned above (Section 2). However, an exact description of the abundance of individual species is still missing.

D. tamaranae is the least abundant species among dragon trees. The whole population of this endemic species of Grand Canaria (Canary Islands), consisted of 86 trees [16]. They were distributed over 44 floristic mapping squares $(500 \times 500 \mathrm{~m})$, but only one specimen occurred in 21 squares and only in three squares were there more than four specimens [205].

Wild populations of D. draco subsp. draco are only known from Tenerife and Gran Canaria [4] and wild specimens of D. draco subsp. draco are extremely rare in Gran Canaria: Almeida Pérez [206] only mentioned one wild specimen and two sub-spontaneous ones. More recently, Marrero and Almeida Pérez [7] show that it is extinct on this island (except for cultivated specimens). Tenerife Island hosted 694 wild specimens that were distributed over 87 floristic mapping squares (500 x $500 \mathrm{~m})$, with a total area of $21.75 \mathrm{~km}^{2}$ [206]. The current populations of D. draco subsp. draco in the rest of the archipelago are all of cultivated origin. This species also occurs in the Madeira archipelago, where it has been reported from the islands of Madeira and Porto Santo, although it is currently regarded as extinct in the latter [4].

D. draco subsp. caboverdeana was found on the Cape Verde Islands, on São Nicolau, Santo Antão, and Fogo. It is considered to be extinct on the islands of São Vicente and São Tiago [79], as growing sub-spontaneously on Santiago and Brava, and as cultivated on all islands [7]. Even though Marrero and Almeida Pérez [7] have not published any information about the abundance of this sub-specie, they took samples from 58 individuals for their study.

Benabid and Cuzin [8] mentioned several thousand individuals of D. draco subsp. ajgal in the Jbel Imsi mountains (western region of Anti-Atlas, Morocco).

D. ombet in Gebel Elba NP (Egypt) occurs in eight wadis with the area of distribution not exceeding $1.327 \mathrm{~km}^{2}$ [20]. In total, 353 trees were recorded. Elnoby et al. [181] recorded a total of 1450 D. ombet trees in south east Egypt. The population of D. ombet in Desa'a Forest (Tigray highlands, Ethiopia) is small, and confined to a small area of shallow soil along the escarpment [198]. A survey in Eastern Sudan, in Erkowit Mountains, found 61 trees of D. ombet within 10 localities in total [62].

The total size of the D. cinnabari population on Soqotra reached $72.3 \mathrm{~km}^{2}$, comprising $62.0 \mathrm{~km}^{2}$ of woodlands, $2.3 \mathrm{~km}^{2}$ of forests, and $8.0 \mathrm{~km}^{2}$ of mixed (mountain) forest [55]. A statistic inventory approach was used for the D. cinnabari forest in Firmihin (Soqotra) [207]. According to the fit model, 66,054 trees were estimated in an area of $6.48 \mathrm{~km}^{2}$. In the whole of Soqotra, up to the elevational limit of $1100 \mathrm{~m}$ a.s.l., a total of 80,134 individual D. cinnabari trees were detected, while using the combination of object-based classification with manual vectorization of remote sensing data. The total area of occupancy was estimated as $519.63 \mathrm{~km}^{2}$ [56].

The populations of D. serrulata were evaluated as geographically isolated and scattered [17] and they very rarely occur in large numbers at a single locality.

Eight populations of D. jayniana were found in Thailand, with a calculated area of occupancy of $32 \mathrm{~km}^{2}$ [9]. This species is abundant at each of these localities. D. kaweesakii of Thailand and Myanmar was estimated to be 2500 mature individuals, with an area of occupancy of $44 \mathrm{~km}^{2}$ [10]. Individual populations contain tens to hundreds of specimens [10].

Only 10 populations of $D$. cambodiana remain on Hainan Island; they grow in distinct habitats and have almost all been seriously isolated. The population size, estimated by measuring the area of each population multiplied by the average density, ranges from 20 to 5000 individuals in total. The abundance of whole population of D. cambodiana was estimated on Hainan Island to be 7590 individuals [11]. 


\subsection{Population Structure}

Population studies of dragon tree species are extremely rare, and only concerned with specific populations of individual species.

Almeida Pérez investigated the population structure of D. tamaranae [16], finding the whole population of this species to comprise 10 dead trees, one old tree, 12 mature, and 63 juvenile trees.

The population of D. ombet in Gebel Elba NP (Egypt) not only has a low regeneration rate, but also poor overall health, and contains only 161 living individuals (46\%), of which only 96 (27\%) were healthy, and only 1\% were young [20]. Similarly, Elnoby et al. [181] report only 870 living trees in South East Egypt, while 580 trees were reported as dead, representing approximately $40 \%$ mortality. Erkowit Mountains (East Sudan) host according to the field survey [62] small remnant population, surprisingly with prevailing young trees. These young specimens are considered to be sprouts from roots of old, dead trees [62].

Adolt and Pavliš [14] evaluated the population structure of D. cinnabari in Firmihin and Hamadero (Soqotra Island). They concluded that the mean age of groups of trees in four localities was 200-294 years, and the mean age of dead trees in the same localities was approximately 350 years. Later, Adolt et al. [207] published a study focused on a detailed investigation of the population structure of D. cinnabari in Firmihin (Soqotra), based on a statistical inventory. They recorded an unbalanced age structure, with insufficient proportion of young trees. From a total estimated number of 66,054 trees, only 545 trees were dead and only 8177 trees had a crown age of less than 100 years. Here, it is necessary to note that this does not represent the total age of the tree, but only the age of the crown. Thus this group of youngest trees (approximately 13\% of the total) is in fact older by at least 100 years. Maděra et al. [56] also clearly demonstrated the over-maturity of $D$. cinnabari populations on Soqotra, with the average crown age within individual populations ranging from 200 to 495 years, and the proportion of both juvenile and early adult ontogenetic stages being less than $5 \%$.

\subsection{Threats and Conservation Status}

The current distribution of individual species is mostly scattered, the populations are small, fragmented, and isolated, with an unbalanced age structure with the young developmental stages often absent [19].

The few studies mentioned above which focus on the population status and structure of dragon trees clearly indicate the high level of threat faced by these iconic species. Overgrazing [23-26,113,208], drought and aridification [20,31], global climate changes [11,18,181], long-term climate oscillation [209], the cutting of leaves, inflorescences, and fruits as fodder for livestock [14,17], longtime resin harvesting [27,32,203], and extraction of recruitment from the wild for use in horticulture [204] are all mentioned as the main factors in the decline of the population of dragon trees. Natural regeneration is mostly absent $[11,14,17,26,112,181,207]$ and populations are overmature $[20,56,207]$. It is also possible that the fragmentation and isolation of dragon tree populations is causing a bottleneck effect [11]. Small, isolated populations may suffer from the effects of population bottlenecks, including increased random genetic drift, and inbreeding and reduced inter-population gene flow, which may result in genetic depletion within populations and population differentiation [11]. This theory remains untested.

Kamel et al. [20] have suggested that $80 \%$ of D. ombet populations in Gebel Elba may soon become extinct. Additionally, in South East Egypt, a high mortality rate has been reported within the population [181]. Severe decline has also been documented for the rest of the D. ombet distribution in NE Africa [198]. In the Sudan, El Azzouni [63] stated that the only population of D. ombet in the country had vanished, and Usama [62] mentioned a small population in Erkowit Mountains. However, this drastic decrease in the population of $D$. ombet in the same area had already been reported by Vetaas [208]. D. ombet, previously dominant, is today found only as isolated saplings. Vetaas [208] explained that this drastic population decline was the result of overgrazing and over-exploitation, due to a transition from a system of transhumance to one of permanent settlements. 
For D. draco, Almeida Pérez [51], making use of toponyms, has clearly demonstrated that there was a greater spread of trees in earlier times. Nowadays, only Tenerife Island hosts a population of wild D. draco subsp. draco. On the other Canary islands it is extinct and only occurs where cultivated [7].

Fertile trees of $D$. tamaranae are extremely rare, which explains why no natural regeneration has been found [210]. Although the germination rate of $D$. tamaranae reaches $50-60 \%$, up to $50 \%$ of the seedlings are not viable [210].

Population decline is clearly documented also for D. cinnabari. According to Attorre et al. [18], this species only occupies $5 \%$ of its potential habitat, although for modeling purposes, the climate data available for Soqotra is poor and no consideration of moisture availability from fog has been made. Adolt and Pavliš [14] predicted the disappearance of the population of D. cinnabari on Soqotra to within 50-144 years. Hubálková [25] predicted a longer period of decline for the D. cinnabari population in Firmihin, suggesting that the number of trees would decrease by $36 \%$ in 100 years. Habrová et al. [21] evaluated the decrease in number of $D$. cinnabari trees in 105 years (by evaluating photographs taken in 1899 and then in 2004) at 44.22\% in the Skand area. Maděra et al. [56] predicted a similar decline in the D. cinnabari population in one hundred years, but, in agreement with Habrová et al. [21], argued that this species is not immediately threatened by extinction, but by over-maturity. Based on a specific climate change scenario that results in increased aridity, Attorre et al. [18] concluded that the current potential habitat of D. cinnabari would be reduced by $45 \%$ in 2080 , although again based on insufficient data for modeling the potential importance of or reduction in orographic precipitation in the future. Only two out of the nine remnant areas should be considered as potential refugia.

Adolt and Pavliš [14] estimated the germination capacity to be $22 \%$, and, when comparing it with the probable number $(611,000)$ of seeds that average tree produces in its lifetime, concluded that $D$. cinnabari has very high potential for regeneration. However, recruitment has been absent for over 100 years $[21,56,207]$. Seeds germinate and young seedlings appear regularly and abundantly after the first rains of September or October in the winter monsoon, but they disappear very quickly. Young seedlings and juvenile trees are found only on inaccessible steep slopes [21].

D. serrulata populations are disappearing at an alarming rate in the Arabian Peninsula. They are destroyed by herders who over the last decades have been using the leaves as fodder for camels, goats, and sheep during the dry season. The stems and branches are also cut to make beehives [17,22]. With little or no natural regeneration in most populations, this species is considered by some to be on the brink of extinction [17], but enough individuals still exist to warrant assessment as Endangered as opposed to Critically Endangered in a recent re-assessment of conservation status (our unpublished data).

In Hainan Island, the mean geographic distance between current $D$. cambodiana populations can be as much as $90.89 \mathrm{~km}$, which might lead to a decrease in gene flow and an increase in the probability of divergent natural selection [11]. Among populations, a significant phylogeographic structure and genetic differentiation were detected, and bottleneck analyses suggest a recent population reduction [49]. It is also predicted that such a long-lived species with a narrow genetic base will not be able to adapt to new selection pressures that are caused by changes in environmental and climate conditions [11]. Zheng et al. [11] did not find any seedlings in most populations, although $D$. cambodiana can produce fertile seeds, with germination of at least $76 \%$ under optimum conditions. They concluded that sexual reproduction in most of the present habitats of $D$. cambodiana is not sufficient for population enlargement and regeneration. The seedling growth of D. cambodiana is best under $37.3 \%$ full irradiance. Because the existing habitat of $D$. cambodiana has been damaged and the seedlings lack shade, it has become unfavourable to the growth of seedling root systems during the dry season. This might be one important reason for the failure of natural regeneration of D. cambodiana [211]. Moreover, the unrestricted exploitation of the wild plants and the destruction of its habitats are external factors that endanger D. cambodiana in Hainan Island [203].

Although D. jayniana is abundant in each of its localities, it is restricted to isolated karst limestone outcrops, which results in a fragmented distribution. Limestone habitats are generally threatened in Thailand by extraction for concrete manufacture, the populations in Saraburi being the most vulnerable 
to this threat. Relative to other species of Dracaena, it is a species with poor fruit set, and the minimal recruitment is extracted for use in horticulture in Thailand [9].

Four species of the dragon tree group (D. cinnabari, D. draco, D. ombet, and D. serrulata) are listed in the International Union for Conservation of Nature Red List [22]. Similarly, D. draco and D. tamaranae both appear on the Red List of endangered species in Spain [205,206,212], with the latter listed as critically endangered. Wilkin et al. $[9,10]$ described the endemic D. jayniana and D. kaweesakii of Thailand and Myanmar as endangered. D. cambodiana is a national second-class protected plant in China; it is listed in the Inventory of Rare and Endangered Plants of China, but it is not recognized as an endangered or protected species in Thailand, Cambodia, Laos, or Vietnam [49]. D. cochinchinenesis is exclusively distributed in China (southern Yunnan and Guangxi provinces), Vietnam, and Laos, and since 1987 it has been listed as a national endangered plant [69].

\subsection{Rescue Programs}

For D. tamaranae, an effective rescue conservation program of Viera y Clavijo Botanic Garden has been running on Gran Canaria for over 15 years [210]. 2891 seeds were collected from the fruit of only five trees from the wild population. Some seeds and seedlings were distributed among botanical gardens in Canary Islands, but also around the world. Some seedlings were replanted in areas of native distribution. In total, 323 seedlings were replanted, with an estimated mortality of 50\% [210].

An efficient in vitro procedure was developed for bud induction, rooting of developing shoots, and greenhouse acclimatization of young plantlets of dragon tree (D. draco) for the multiplication of this endangered tree [213]. In vitro culture could be used for the micropropagation of dragon tree species with the aim of reintroduction in its native ecosystem where natural regeneration is no longer observed.

Many dragon trees have been cultivated near houses, hotels, in garden, and in parks: D. draco subsp. draco on the Canary Islands [51] and subsp. caboverdeana on the Cape Verde Islands [7]. This can help to save these species.

Efforts of Mendel University in Brno (Czech Republic) to reforest D. cinnabari in situ on Soqotra have been documented since 2006, when more than 700 three-year-old seedlings were planted in the Ras Ayre area [113]. The mortality rate was $4.9 \%$ over the first three years but increased to $26.9 \%$ after the fencing was broken. After repairing the fence, the mortality rate decreased to 1.2-1.8\% [113]. Without fencing it is not possible to plant any trees on Soqotra due to the strong impact of grazing [26].

As a rescue program of Oman Botanic Garden for trees affected by road construction, the study of Al Hosni et al. [214] shows that it is possible to re-plant mature trees of D. serrulata. However, the survival rate decreases as the trees grow in size: the total mortality one year after re-planting was $36 \%$.

Long-lived, sporadically recruiting plant species in human-dominated landscapes, like the dragon trees, need more dynamic adaptive management programs to preserve these iconic species for future generations [215].

\section{Future Research Needed}

Below is a list of research topics not sufficiently addressed regarding dragon trees. These knowledge gaps must be filled and actions implemented in order to fully understand these iconic species, and conserve them and their values and functions for the future.

Historically and archaeologically, the harvesting of dragon's blood on Soqotra can be traced from at least the mid-first century AD to the post medieval period. However, despite the scale of this trade, there are very few references concerning the actual harvesting and management of dragon's blood resin. To determine this, it was necessary to combine archaeological, historical, and ecological evidence, which demonstrates that there was likely to have been an intensive island-wide harvesting and management strategy for dragon's blood from at least the mid-first century AD, a strategy for the harvesting and collection likely to have been managed locally. An assessment of contemporary harvesting and markets is also required to ensure continued sustainable use. 
All of the available information about Dracaena leaf microstructure originates from individuals of different age, which could result in a greater variability in observed traits. Information regarding functional traits, such as specific leaf area and specific hydraulic conductivity, are completely lacking or are limited to two species only (D. draco, D. cinnabari).

It is important to emphasize that the current understanding of the development, structure, and functional significance of the secondary tissue of dragon trees are mostly derived from anatomical observations of D. draco and D. cinnabari. More anatomically and physiologically oriented studies are needed to achieve deeper insights into secondary growth in dragon trees.

Further studies are definitely required to comprehensively elucidate the process of the secretion of the red resin in dragon trees and, hence, enable controlled and reasonable dragon's blood extraction for commercial purposes.

The lack of studies on basic plant physiology is the biggest gap in research on dragon trees. The adaptations of dragon trees to stress factors in an arid environments that are affected by global climate change, especially physiological processes, are not sufficiently explored. Future studies on transpiration, photosynthesis, metabolism, nitrogen assimilation, mineral nutrition, and capturing moisture from fog and cloud are needed.

The lack of studies on genetic and environmental factors affecting the production and chemical composition of Dracaena species resin points out the future research directions. The evaluation of the pharmacological activities of the bioactive resin compounds while using different cell lines and animal models should be carried out. Further investigations should be made regarding the volatile metabolites of the resins, as there are only a limited number of reports focusing on this topic.

Except for D. draco and D. cinnabari, no information has been published regarding the growth dynamic and age estimation of other dragon tree species. The description of the growth of $D$. draco was based on only a few specimens, mostly the biggest and oldest trees. Measurements of young trees were made on cultivated trees, outside their area of origin, and the information is sketchy. Only the growth of $D$. cinnabari was investigated in situ and on a sufficient number of trees, and, even then, the information is incomplete. For example, we still do not understand how to estimate age reliably, or the growth dynamics of the stem before the first flowering. Additionally, seasonality in flowering has not been investigated, which is the most important input for modelling age estimation.

Population inventories are missing in many areas of distribution, especially for African and Arabian species. Information regarding the detailed distribution of individual species and their population structure is urgently needed, because most species are severely threatened with declining populations. Further, population genetic analyses are required for assessing contemporary and historical breeding systems and potential bottlenecks to inform conservation management strategies and actions. Conservation management has to be started, beginning with a study of both natural and artificial regeneration, and methods of effective protection for recently matured or overmature populations devised. It is clear that the full IUCN Red List assessments and reassessments are required for all species of the dragon tree group, in order to inform conservation actions globally and nationally in range states.

\section{Conclusions}

An exhaustive review focusing on dragon trees, the iconic monocotyledon species with an arborescent form of growth and excretion of the famous red resin, dragon's blood, was carried out. The main characteristics of Dracaena species with the respective references are shown in Table 3 . D. draco and D. cinnabari are the most investigated species, with some species still poorly known (e.g., recently described Asian species, D. serrulata, D. schizantha and D. ellenbeckiana). The most extensive research articles were published on the chemical composition of resin, its bioactive effects and also on anatomy and morphology, while physiology is the least explored field in Dracaena research. 
Table 3. Main characteristic of Dracaena species with the respective references

\begin{tabular}{|c|c|c|c|c|c|c|c|c|c|c|}
\hline Species & Taxonomy & Evolution & Distribution & Anatomy, morphology & $\begin{array}{c}\text { Ontogenetic } \\
\text { cycle }\end{array}$ & $\begin{array}{c}\text { Water } \\
\text { relations }\end{array}$ & Resin, ethnobotany & Ecology & Populations & $\begin{array}{c}\text { Threat, } \\
\text { conservation }\end{array}$ \\
\hline Dracaena spp. & $\begin{array}{c}1,2,3,33,34,35 \\
36,37,38,42\end{array}$ & $\begin{array}{c}13,33,35,42,45 \\
46,97\end{array}$ & 85 & $\begin{array}{l}4,39,40,41,42,43,44 \\
71,72,77,78,84,86,87 \\
88,89,90,91,94,96,97\end{array}$ & & 86 & & 97 & & \\
\hline D.cinnabari & 15,27 & & $24,27,55,56$ & $4,43,44,73,81,83,87$ & $\begin{array}{c}14,18,111,112, \\
113,114\end{array}$ & $\begin{array}{r}23,83,124 \\
125,126,127\end{array}$ & $\begin{array}{c}27,107,129,130,131 \\
134,135,145,146,148, \\
149,153,157,158,159 \\
160,161,162,163,164 \\
165,166,167,168,169 \\
170,176,178,179\end{array}$ & $\begin{array}{c}4,23,24,28,29 \\
111,184,194,195 \\
196\end{array}$ & $\begin{array}{c}14,18,21,25, \\
207\end{array}$ & $\begin{array}{c}14,18,19,21, \\
25,26,32, \\
113,207,215\end{array}$ \\
\hline D.serrulata & 17 & & $4,17,57,58$ & $4,43,44$ & 4 & & 131,183 & $4,17,31$ & 17 & 17,214 \\
\hline $\begin{array}{l}\text { D.ombet subsp. } \\
\text { ombet }\end{array}$ & 6 & & $\begin{array}{c}4,6,20,59,60,61 \\
62,63\end{array}$ & $4,43,44$ & 4 & & 131,182 & $4,20,193,197,198$ & $20,63,181$ & $\begin{array}{l}20,63,181 \\
208\end{array}$ \\
\hline $\begin{array}{l}\text { D.ombet subsp. } \\
\text { schizantha }\end{array}$ & 6 & & $3,6,61,64,65$ & $4,43,44,87$ & 4 & & 129 & 4,61 & & \\
\hline D. ellenbeckiana & 6 & & 6 & 44,87 & & & & $61,199,200,201$ & & \\
\hline $\begin{array}{l}\text { D.draco subsp. } \\
\quad \text { draco }\end{array}$ & & & $51,52,53,54$ & $\begin{array}{r}4,43,44,70,74,75,76 \\
82,83,87,93,95,99,106\end{array}$ & $\begin{array}{c}4,76,115,116,117 \\
118,119,120\end{array}$ & $\begin{array}{c}83,109,125 \\
126,128\end{array}$ & $\begin{array}{c}107,110,129,131,132, \\
138,139,148\end{array}$ & $\begin{array}{c}4,30,106,184,185 \\
188,190\end{array}$ & & $206,212,213$ \\
\hline $\begin{array}{l}\text { D.draco subsp. } \\
\text { ajgal }\end{array}$ & 8 & & 8 & & & & 131,143 & $4,8,188$ & & \\
\hline $\begin{array}{l}\text { D.draco subsp. } \\
\text { caboverdeana }\end{array}$ & 7 & & 7,50 & & 7,79 & & & $7,191,192$ & & \\
\hline D.tamaranae & 4,5 & 5 & 4,16 & 4,43 & & & 132 & 4,16 & 16 & $\begin{array}{c}16,205,210, \\
212\end{array}$ \\
\hline D.cochinchinensis & & 47 & 68,69 & 68,102 & & & $\begin{array}{c}69,102,107,108,129 \\
133,136,137,140,141 \\
144,147,150,151\end{array}$ & 202 & & \\
\hline $\begin{array}{l}\text { D.cambodiana } \\
\text { D kaweesakii }\end{array}$ & 10 & $47,48,49,105$ & $\begin{array}{c}11,49,66,67 \\
10\end{array}$ & $\begin{array}{l}44,87,103,105 \\
43\end{array}$ & 10,11 & & $103,105,129,155$ & $\begin{array}{c}11,49,203 \\
10\end{array}$ & 11 & 11,211 \\
\hline $\begin{array}{l}\text { D. kaweesakil } \\
\text { D. jayniana }\end{array}$ & 9 & & $\begin{array}{l}10 \\
9\end{array}$ & 43 & & & & 9 & & \\
\hline D. yuccifolia & & & 10 & & & & & & & \\
\hline D.americana & 12 & & 12 & 87 & 12 & & & & & \\
\hline
\end{tabular}


Author Contributions: All co-authors were involved in writing-original draft preparation according to their specialization (P.M., Sections 1, 4 and 8; J.W.-S., P.H., A.F., Sections 1, 2.1 and 2.2; H.H., P.V., Section 2.3; J.J.-M., R.G., R.P., R.J., Section 3; H.K., Section 4; N.N., Section 5; L.V., K.L., Sections 6.1 and 6.2; J.J.V.R., Section 6.3 and 6.4 ; M.M., Section 6.5; M.R., Section 7; J.J.V.R., M.M., A.F. also in English revision and P.M. in final manuscript editing. All authors have read and agreed to the published version of the manuscript.

Funding: This research was partially funded by UNE/GEF, grant number 5347.

Conflicts of Interest: The authors declare no conflict of interest.

\section{References}

1. Mabberley, D.J. Mabberley's Plant-Book, 3rd ed.; Cambridge University Press: New York, NY, USA, 2008; p. 1021.

2. Bos, J. Dracaena. In The Families and Genera of Vascular Plants; Kubitzki, K., Ed.; Springer: Berlin/Heidelberg, Germany, 1998; Volume III, pp. 238-241.

3. Govaerts, R.; Zonneveld, B.J.M.; Zona, S.A.; World checklist of Asparagaceae. Facilitated by the Royal Botanic Gardens, Kew. Available online: http://apps.kew.org/wcsp/ (accessed on 22 December 2019).

4. Marrero, A.; Almeida, S.R.; Martín-González, M. A new species of the wild Dragon Tree, Dracaena (Dracaenaceae) from Gran Canaria and its taxonomic and biogeographic Implications. Bot. J. Linn. Soc. 1998, 128, 291-314.

5. Marrero, A. Dracaena tamaranae, el género dracaena y otros afines: Análisis morfológico para un aproximación filogenética. El Mus. Canar. 2000, 55, 301-334.

6. Bos, J.J.; Teketay, D. Dracaenaceae. In Flora of Ethiopia and Eritrea, 1st ed.; Edwards, S., Ed.; Uppsala University: Uppsala, Sweden, 1997; Volume 5, pp. 76-84.

7. Marrero, A.; Almeida, S.R. A new subspecies, Dracaena draco (L.) L. subsp. caboverdeana Marrero Rodr. $\mathcal{E}$ R. Almeida (Dracaenaceae) from Cape Verde Island. Int. J. Geobot. Res. 2012, 2, 35-40. [CrossRef]

8. Benabid, A.; Cuzin, F. Populations de dragonnier (Dracaena draco L. subsp. aigal Benabid et Cuzin) au Maroc: Valeurs taxinomique, biogéographique et phytosociologique. C. R. Acad. Sci. Paris, Sciences de la vie 1997, 320, 267-277.

9. Wilkin, P.; Suksathan, P.; Keeratikiat, K.; Van Welzen, P.; Wiland-Szymanska, J. A new threatened endemic species from central and northeastern Thailand, Dracaena jayniana (Asparagaceae: Tribe Nolinoideae). Kew. Bull. 2012, 67, 697-705. [CrossRef]

10. Wilkin, P.; Suksathan, P.; Keeratikiat, K.; Van Welzen, P.; Wiland-Szymanska, J. A new species from Thailand and Burma, Dracaena kaweesakii Wilkin \& Suksathan (Asparagaceae subfamily Nolinoideae). PhytoKeys 2013, 26, 101-112. [CrossRef]

11. Zheng, D.J.; Xie, L.S.; Zhu, J.H.; Zhang, Z.L. Low genetic diversity and local adaptive divergence of Dracaena cambodiana (Liliaceae) populations associated with historical population bottlenecks and natural selection: An endangered long-lived tree endemic to Hainan Island, China. Plant Biol. 2012, 14, 828-838. [CrossRef]

12. Zona, S.; Álvarez De Zayas, A.; Orellana, R.; Oviedo, R.; Jestrow, B.; Francisco-Ortega, J. Dracaena L. (Asparagaceae) in the New World: Its history and Botany. Vieraea 2014, 42, 219-240.

13. Denk, T.; Güner, H.T.; Grimm, G.W. From mesic to arid: Leaf epidermal features suggest preadaptation in Miocene dragon trees (Dracaena). Rev. Paleobotany Palynol. 2014, 200, 211-228. [CrossRef]

14. Adolt, R.; Pavliš, J. Age structure and growth of Dracaena cinnabari populations on Socotra. Trees-Struct. Funct. 2004, 18, 43-53. [CrossRef]

15. Bayley Balfour, I. Botany of Socotra, 1st ed.; Royal Society of Edinburgh: Edinburgh, UK, 1888; p. 446.

16. Almeida Pérez, R.S. Censo, distribución, habitat y estado de conservation de Dracaena tamaranae A.Marrero, R.S.González-Martín. Gran Canaria, Islas Canarias. Bot. Macarónesica 2003, 24, 39-56.

17. Lavranos, J.J. A new, arborescent subspecies of Dracaena from Saudi Arabia. Cactus Succul. J. 2017, 89, 148-152. [CrossRef]

18. Attorre, F.; Francesconi, F.; Taleb, N.; Scholte, P.; Saed, A.; Alfo, M.; Bruno, F. Will dragonblood survive the next period of climate change? Current and future potential distribution of Dracaena cinnabari (Socotra, Yemen). Biol. Conserv. 2007, 138, 430-439. [CrossRef]

19. Van Damme, K.; Banfield, L. Past and present human impacts on the biodiversity of Socotra Island (Yemen): Implications for future conservation. Zool. Middle East 2011, 3, 31-88. [CrossRef] 
20. Kamel, M.; Ghazaly, U.M.; Callmander, M.W. Conservation status of the Endangered Nubian dragon tree Dracaena ombet in Gebel Elba National Park, Egypt. Oryx 2015, 49, 704-709. [CrossRef]

21. Habrová, H.; Čermák, Z.; Pavliš, J. Dragon's blood tree-Threatened by overmaturity, not by extinction: Dynamics of a Dracaena cinnabari woodland in the mountains of Soqotra. Biol. Conserv. 2009, 142, 772-778. [CrossRef]

22. IUCN red list of threatened species version 2017.2. Available online: http://www.iucnredlist.org (accessed on 25 October 2017).

23. Brown, G.; Mies, B.A. Vegetation Ecology of Socotra. Plant and Vegetation 7, 1st ed.; Springer: Dordrecht, Germany, 2012; p. 379.

24. Habrová, H. Geobiocoenological differentiation as a tool for sustainable land-use of Soqotra Island (Republic of Yemen). Ekológia Bratisl. 2004, 23, 47-57.

25. Hubálková, I. Prediction of Dragon's Blood Tree (Dracaena cinnabari Balf.) stand sample density on Soqotra Island. J. Landsc. Ecol. 2011, 4, 5-17. [CrossRef]

26. Habrová, H.; Pavliš, J. Dynamic response of woody vegetation on fencing protection in semi-arid areas; Case study: Pilot exclosure on the Firmihin Plateau, Socotra island. Saudi J. Biol. Sci. 2017, 24, 338-346. [CrossRef]

27. Miller, A.G.; Morris, M.; Diccon, A.; Atkinson, R. Ethnoflora of the Soqotra Archipelago, 1st ed.; Royal Botanic Garden: Edinburgh, UK, 2004; p. 759.

28. Rejžek, M.; Svátek, M.; Šebesta, J.; Adolt, R.; Maděra, P.; Matula, R. Loss of a single tree species will lead to an overall decline in plant diversity: Effect of Dracaena cinnabari Balf. f. on the vegetation of Socotra Island. Biol. Conserv. 2016, 196, 165-172. [CrossRef]

29. García, C.; Vasconcelos, R. The beauty and the beast: Endemic mutualistic interactions promote community-based conservation on Socotra Island (Yemen). J. Nature Conserv. 2017, 35, 20-23. [CrossRef]

30. González-Castro, A.; Pérez-Pérez, D.; Romero, J.; Nogales, M. Unraveling the Seed Dispersal System of an Insular "Ghost" Dragon Tree (Dracaena draco) in the Wild. Front. Ecol. Evol. 2019, 7, 39. [CrossRef]

31. Hildebrandt, A.; Eltahir, E.A.B. Forest on the edge: Seasonal cloud forest in Oman creates its own ecological niche. Geophys. Res. Lett. 2006, 33, L11401. [CrossRef]

32. Scholte, P.; Al-Okaishi, A.; Suleyman, A.S. When conservation precedes development: A case study of the opening up of the Socotra archipelago, Yemen. Oryx 2011, 45, 401-410. [CrossRef]

33. Lu, P.-L.; Morden, C.W. Phylogenetic Relationships among Dracaenoid Genera (Asparagaceae: Nolinoideae) Inferred from Chloroplast DNA Loci. Syst. Bot. 2014, 39, 90-104. [CrossRef]

34. Angiosperm Phylogeny Group. An update of the Angiosperm Phylogeny Group classification for the orders and families of flowering plants: APG IV. Bot. J. Linn. Soc. 2016, 181, 1-20. [CrossRef]

35. Lu, P.-L.; Morden, C.W. Phylogenetics of the plant genera Dracaena and Pleomele (Aparagaceae). Bot. Orient. J. Plant Sci. 2010, 7, 64-72. [CrossRef]

36. Kuntze, O. Revisio generum plantarum: vascularium omnium atque cellularium multarum secundum leges nomenclaturae internationales cum enumeratione plantarum exoticarum in itinere mundi collectarum, 2nd ed.; A. Felix: Leipzig, Germany, 1891; p. 374.

37. Bos, J.J. Dracaena in West Africa. Meded. Landbouwhogesch. Wagening. 1984, 84, 1-126.

38. Brown, N.E. Notes on the genera Cordyline, Dracaena, Pleomele, Sansevieria, and Taetsia. Bull. Misc. Inf. (Royal Bot. Gard. Kew.) 1914, 8, 273-279. [CrossRef]

39. Wiland-Szymańska, J.; Klimko, M. Differentiation of leaf anatomy of the genera Dracaena L. and Sansevieria Thunb. (Dracaenaceae). In Abstracts XVII International Botanical Congress; International Association of Botanical and Mycological Societies: Vienna, Austria, 16 July 2005; p. 328.

40. Jankalski, S. The Sansevieria inflorescence and new sections proposed. Sansevieria 2009, 19, 8-10.

41. Mansfeld, P. Die Systematik der Gattung Sansevieria (Asparagaceae)-ein aktueller Stand. Sansevieria Online 2015, 3, 20-29.

42. Takawira-Nyenya, R.; Mucina, L.; Cardinal-Mcteague, W.; Thiele, K. Sansevieria (Asparagaceae, Nolinoideae) is a herbaceous clade within Dracaena: Inference from non-coding plastid and nuclear DNA sequence data. Phytotaxa 2018, 376, 254-276. [CrossRef]

43. Klimko, M.; Nowińska, R.; Wilkin, P.; Wiland-Szymańska, J. Comparative leaf micromorphology and anatomy of the dragon tree group of Dracaena (Asparagaceae) and their taxonomic implications. Plant Syst. Evol. 2018. [CrossRef] 
44. Klimko, M.; Nowińska, R.; Jura-Morawiec, J.; Wiland-Szymańska, J.; Wilkin, P. Pollen morphology of selected species of the genera Chrysodracon and Dracaena (Asparagaceae, subfamily Nolinoideae) and its systematic implications. Plant Syst. Evol. 2018. [CrossRef]

45. Suárez-Rodríguez, C. A Dracaenites Saporta fossil in the Pliocene of Gran Canaria, Canary Islands. Vieraea 2013, 41, 385-388.

46. Baldwin, A.; Webb, R. The Genus Sansevieria: An introduction to molecular (DNA) analysis and preliminary insights to intrageneric relationships. Sansevieria 2016, 34, 14-26.

47. Zhang, Z.; Zhang, Y.; Song, M.; Guan, Y.; Ma, X. Species identification of Dracaena using the complete chloroplast genome as a super-barcode. Front. Pharmacol. 2019. [CrossRef]

48. Zhua, Z.-X.; Mub, W.-X.; Wanga, J.-H.; Zhanga, J.-R.; Zhaoa, K.-K.; Friedmanc, C.R.; Wanga, H.-F. Complete plastome sequence of Dracaena cambodiana (Asparagaceae): A species considered "Vulnerable" in Southeast Asia. Mitochondrial DNA Part B Resour. 2018, 3, 620-621. [CrossRef]

49. Zhao, J.-L.; Zhang, L.; Dayanandan, S.; Nagaraju, S.; Liu, D.-M.; Li, Q.-M. Tertiary origin and pleistocene diversification of dragon blood tree (Dracaena cambodiana-Asparagaceae) populations in the Asian tropical forests. PLoS ONE 2013, 8, e60102. [CrossRef]

50. Rivas Martinez, S. Ensayo geobotánico global sobre la Macaronesia. In Homenaje al Prof Dr. Wolfredo Wildproel de la Torre, 1st ed.; Beltrán Tejera, E., Afonso-Carrillo, J., García Gallo, A., Rodríguez Delgado, O., Eds.; Instituto de Estudios Canarios: La Laguna (Santa Cruz de Tenerife), Spain, 2009; pp. 256-296.

51. Almeida Pérez, R.S. Sobre la presencia de Dracaena draco (L.) L. En Gran Canaria (Islas Canarias): Aportación corológica, estado actual y significación biogeográfica. Bot. Macarónesica 2003, 24, 17-38.

52. Turland, N.J. Agavaceae. In Flora of Madeira; Press, J.R., Short, M.J., Eds.; HMSO, Natural History Museum: London, UK, 1995; pp. 391-392.

53. Santos, A. Vegetación y flora de La Palma; Editorial Interinsular Canaria: Santa Cruz de Tenerife, Spain, 1983.

54. Rivas-Martínez, S.; Wildpret, W.; Del Arco, M.; Rodríguez, O.; Pérez de Paz, P.L.; Garcia-Gallo, A.; Acebes, J.R.; Díaz, T.E.; Fernández-González, F. Las comunidades vegetales de la isla de Tenerife (islas Canarias). Itinera Geobotánica 1993, 7, 169-374.

55. Král, K.; Pavliš, J. The first detailed land cover map of Socotra Island by Landsat/ETM+ data. Int. J. Remote Sens. 2006, 27, 3239-3250. [CrossRef]

56. Maděra, P.; Volařík, D.; Patočka, Z.; Kalivodová, H.; Divín, J.; Rejžek, M.; Vybíral, J.; Lvončík, S.; Jeník, D.; Hanáček, P.; et al. Sustainable land use management needed to conserve the dragon's blood tree of Socotra Island, a vulnerable endemic umbrella species. Sustainability 2019, 11, 3557. [CrossRef]

57. Collenette, S. An Illustrated Guide to the Flowers of Saudi Arabia; Scorpion Publishing: London, UK, $1985 ;$ p. 266.

58. Miller, A.G.; Cope, T.A. Flora of the Arabian Peninsula and Socotra; Edinburgh University Press: Edinburgh, UK, 1996; Volume 1, p. 438.

59. Ghazali, U. The globally endangered Dracaena ombet monitoring and assessment project in Gabel Elba protected area, Egypt. Final report, conservation leadership programme. 2008. Available online: http: //www.conservationleadershipprogramme.org/ (accessed on 5 December 2013).

60. Zahran, M.A.; Willis, A.J. The Vegetation of Egypt; Springer: Berlin/Heidelberg, Germany, 2009; p. 437.

61. Friis, I. Forests and Forest Trees of Northeast Tropical Africa; Their natural habitats and distribution patterns in Ethiopia, Djibouti and Somalia; HMSO: Middlesex, UK, 1992; p. 396.

62. El Azzouni, M. Conserving Dracaena Ombet, Egypt's Dragon Tree. PlantTalk 2003, 3, 38-39.

63. Usama, M. Dracaena Ombet Status Survey in Erkowit Mountains in East Sudan; Project Report; Dragon Tree Land Project: Mount Erkowit, Sudan, 2015; p. 21.

64. Baker, J.G. Dracaena schizantha Baker sp. nov. In The Journal of Botany, New Series; Trimen, H., Ed.; Ranken \& Co.: London, UK, 1877; Volume 6, p. 71.

65. Thulin, M. Dracaenaceae. In Flora of Somalia; Thulin, M., Ed.; Royal Botanic Gardens Kew: London, UK, 1995; Volume 4, pp. 27-29.

66. Chen, X.; Turland, N.J. Dracaena Vandelli ex Linnaeus. In Flora of China; Wu, Z.Y., Raven, P.H., Eds.; Science Press, and Missouri Botanical Garden Press: Beijing, China; Louis, MO, USA, 2000; Volume 24, pp. 73-263.

67. Sarma, J.; Barbhuiya, H.A.; Dey, S. First report of a strict Dragon Tree species (Dracaena cambodiana: Asparagaceae) from India. J. Bot. Res. Inst. of Texas, 2019, 13, 241-247. 
68. Wang, X.H.; Zhang, C.H.; Yang, L.L.; Gomes-Laranjo, J. Production of dragon's blood in Dracaena cochinchinensis plants by inoculation of Fusarium proliferatum. Plant Sci. 2011, 180, 292-299. [CrossRef] [PubMed]

69. Fan, J.Y.; Yi, T.; Sze-To, C.M.; Zhu, L.; Peng, W.L.; Zhang, Y.Z.; Zhao, Z.Z.; Chen, H.B. A Systematic Review of the Botanical, Phytochemical and Pharmacological Profile of Dracaena cochinchinensis, a Plant Source of the Ethnomedicine “Dragon's Blood". Molecules 2014, 19, 10650-10669. [CrossRef]

70. Beyhl, F.E. Two different growth forms of Dracaena draco L. (Monocotyledones: Liliales: Agavaceae). Bol. Mus. Munic. Funchal. 1995, 4, 91-95.

71. Cheadle, V.I. Secondary growth by means of a thickening ring in certain monocotyledons. Bot. Gaz. 1937, 98, 535-555. [CrossRef]

72. Carlquist, S. Monocot Xylem Revisited: New Information, New Paradigms. Bot. Rev. 2012, 78, 87-153. [CrossRef]

73. Hubálková, I.; Houška, J.; Kubíček, J.; Mazal, P.; Pavliš, J.; Pohořalý, J.; Vačkářová, G.; Duchoslav, M. Preliminary anatomical study on secondary thickening parts of endemic Dracaena cinnabari Bal.fil. from the Soqotra island. Wood Res. 2017, 62, 67-77.

74. Krawczyszyn, J.; Krawczyszyn, T. Massive aerial roots growth and form of Dracaena draco. Trees-Struct. Funct. 2014, 28, 757-768. [CrossRef]

75. Beyhl, F.E. Dragon-trees (Dracaena draco L.) with abberant growth forms (Monocotyledons: Liliflorae: Agavaceae). Arquipélago. Life Mar. Sci. 2001, 2, 101-103.

76. Krawczyszyn, J.; Krawczyszyn, T. Photomorphogenesis in Dracaena draco. Trees-Struct. Funct. 2016, 30, 647-664. [CrossRef]

77. Zimmermann, M.H.; Tomlinson, P.B. The vascular system in the axis of Dracaena fragrans (Agavaceae) 1. Distribution and development of primary strands. J. Arnold Arbor. 1969, 51, 370-383.

78. Haushahn, T.; Speck, T.; Masselter, T. Branching morphology of decapitated arborescent monocotyledons with secondary growth. Am. J. Bot. 2014, 101, 754-763. [CrossRef]

79. Byström, K. Dracaena draco L. in the Cape Verde Islands. Acta Horti.-Gotobg. 1960, 23, 179-214.

80. Lyons, G. In search of dragons or: The plant that roared. Cactus Succul. J. 1974, 46, 267-282.

81. Beyhl, F.E.; Mies, B.A. Die Wuchsformen des Drachenbaums (Dracaena cinnabari Balf. Fil.) auf der Insel Soqotra-growth forms of the Dragon tree (Dracaena cinnabari Balf. Fil.) of Soqotra island. Acta Biol. Benrodis $2007,14,55-66$.

82. Jura-Morawiec, J. Rhythmic growth and age estimation of aerial roots in Dracaena draco (Asparagaceae). Trees 2019, 33, 1513-1518. [CrossRef]

83. WCSP World Checklist of Selected Plant Families. Facilitated by the Royal Botanic Gardens, Kew. Available online: http://wcsp.science.kew.org/ (accessed on 29 November 2019).

84. Nadezhdina, N.; Plichta, R.; Nadezhdin, V.; Gebauer, R.; Jupa, R.; Habrová, H.; Maděra, P. A comparative structural and functional study of leaf traits and sap flow in Dracaena cinnabari and Dracaena draco seedlings. Funct. Plant Biol. 2015, 42, 1092-1105. [CrossRef]

85. Rudall, P.; Conran, J.G.; Chase, M.W. Systematics of Ruscaceae/Convallariaceae: A combined morphological and molecular investigation. Bot. J. Linn. Soc. 2000, 134, 73-92. [CrossRef]

86. Jupa, R.; Plichta, R.; Paschová, Z.; Nadezhda, N.; Gebauer, R. Mechanisms underlying the long-term survival of the monocot Dracaena marginata under drought conditions. Tree Physiol. 2017, 37, 1-16. [CrossRef] [PubMed]

87. Klimko, M.; Wiland-Szymańska, J. Scanning electron microscopic studies of leaf surface in taxa of genus Dracaena L. (Dracaenaceae). Bot.-Steciana 2008, 12, 117-127.

88. Rudall, P. Lateral meristems and stem thickening growth in monocotyledons. Bot. Rev. 1991, 57, 150-163. [CrossRef]

89. Rudall, P.J. New records of secondary thickening in monocotyledons. Iawa J. 1995, 16, 261-268. [CrossRef]

90. Jura-Morawiec, J.; Tulik, M.; Iqbal, M. Lateral Meristems Responsible for Secondary Growth of the Monocotyledons: A Survey of the State of the Art. Bot. Rev. 2015, 81, 150-161. [CrossRef]

91. Tomlinson, P.B.; Zimmermann, M.H. Vascular anatomy of monocotyledons with secondary growth-An introduction. J. Arnold Arbor. 1969, 50, 159-179.

92. Evert, R. Esau's Plant Anatomy: Meristems, Cells, and Tissues of the Plant Body: Their Structure, Function, and Development, 3rd ed.; John Wiley and Sons: Hoboken, NJ, USA, 2006; p. 624. 
93. Jura-Morawiec, J. Formation of amphivasal vascular bundles in Dracaena draco stem in relation to rate of cambial activity. Trees-Struct. Funct. 2015, 29, 1493-1499. [CrossRef]

94. Zimmermann, M.H.; Tomlinson, P.B. The vascular system in the axis of Dracaena fragrans (Agavaceae) 2. Distribution and development of secondary tissue. J. Arnold Arbor. 1970, 51, 478-491.

95. Jura-Morawiec, J. Atypical origin, structure and arrangement of secondary tracheary elements in the stem of the monocotyledonous dragon tree, Dracaena draco. Planta 2017, 245, 93-99. [CrossRef]

96. Scott, D.H.; Brebner, G. On the secondary tissues in certain monocotyledons. Ann. Bot. 1893, 7, $22-62$. [CrossRef]

97. Waterhouse, J.T. The phylogenetic significance of Dracaena-Type growth. Proc. Linn. Soc. New South Wales 1987, 109, 129-138.

98. De Bary, A. Comparative Anatomy of the Vegetative Organs of the Phanerogams and Ferns, 1st. ed.; Claredon Press: Oxford, UK, 1884.

99. Jura-Morawiec, J.; Wiland-Szymanska, J. A novel insight into the structure of amphivasal secondary bundles on the example of Dracaena draco L. stem. Trees-Struct. Funct. 2014, 28, 871-877. [CrossRef]

100. Zimmermann, M.H.; Brown, C.L. Trees Structure and Function; Springer: New York, NY, USA, 1971; p. 336.

101. Spicer, R. Symplasmic networks in secondary vascular tissues: Parenchyma distribution and activity supporting long-distance transport. J. Exp. Bot. 2014, 65, 1829-1848. [CrossRef] [PubMed]

102. Wang, X.H.; Zhang, C.H.; Yang, X.H.; Lou, J.D.; Cao, Q.; Gomes Laranjo, J. Enhanced dragon's blood prodution in Dracaena cochinchinesis by elicitation of Fusarium oxysporum strands. J. Med. Plants Res. 2010, 4 , 2633-2640. [CrossRef]

103. Cui, J.L.; Wang, C.L.; Guo, S.X.; Xiao, P.G.; Wang, M.L. Stimulation of dragon's blood accumulation in Dracaena cambodiana via fungal inoculation. Fitoterapia 2013, 87, 31-36. [CrossRef]

104. Wang, X.H.; Zhang, W.Y.; Gomes-Laranjo, J. Screen of micro-organisms for inducing the production of dragon's blood by leaf Dracaena cochinchinensis. Lett. Appl. Microbiol. 2010, 51, 504-510. [CrossRef]

105. Ding, X.; Mei, W.; Huang, S.; Wang, H.; Zhu, J.; Hu, W.; Ding, Z.; Tie, W.; Peng, S.; Dai, H. Genome survey sequencing for the characterization of genetic background of Dracaena cambodiana and its defense response during dragon's blood formation. PLoS ONE 2018, 13, e0209258. [CrossRef]

106. Jura-Morawiec, J.; Tulik, M. Morpho-anatomical basis of dragon's blood secret in Dracaena draco stem. Flora 2015, 213, 1-5. [CrossRef]

107. Gupta, D.; Bleakley, B.; Gupta, R.K. Dragon's blood: Botany, chemistry and therapeutic uses. J. Ethnopharmacol. 2008, 115, 361-380. [CrossRef] [PubMed]

108. Wang, X.H. Flavones formed from xylem stem of Dracaena cochinchinensis by co-culture of fungus strain and bacteria strain. Nat. Prod. Res. Dev. 2007, 19,11-15.

109. Jura-Morawiec, J.; Tulik, M. Dragon's blood secretion and its ecological significance. Chemoecology 2016, 26, 101-105. [CrossRef]

110. González, A.G.; Hernández, J.C.; Leôn, F.; Padrôn, J.I.; Estévez, F.; Quintana, J.; Bermejo, J. Steroidal saponins from the bark of Dracaena draco and their cytoctoxic activity. J. Nat. Prod. 2003, 66, 793-798. [CrossRef] [PubMed]

111. Habrová, H.; Maděra, P. Ecology of Dragon's blood tree (Dracaena cinnabari) communities on the Socotra Island. In Evaluation of State and Development of Forest Geobiocoenosis; Faculty of Forestry and Wood, Technology, Polehla, P., Eds.; Mendel University: Brno, Czech Republic, 2004; pp. 120-126.

112. Adolt, R.; Habrová, H.; Maděra, P. Crown age estimation of a monocotyledonous tree species Dracaena cinnabari using logistic regression. Trees-Struct. Funct. 2012, 26, 1287-1298. [CrossRef]

113. Maděra, P.; Habrová, H.; Šenfeldr, M.; Kholová, I.; Lvončík, S.; Ehrenbergerová, L.; Roth, M.; Nadezhdina, N.; Němec, P.; Rosenthal, J.; et al. Growth dynamics of endemic Dracaena cinnabari Balf. f. of Socotra Island suggest essential elements for a conservation strategy. Biológia 2018. [CrossRef]

114. Hubálková, I.; Maděra, P.; Volařík, D. Growth dynamics of Dracaena cinnabari under controlled conditions as the most effective way to protect endangered species. Saudi. J. Biol. Sci. 2017, 24, 1445-1452. [CrossRef]

115. Symon, D.E. The growth of Dracaena draco-dragon's blood tree. J. Arnold Arbor. 1974, 55, 51-58.

116. Mägdefrau, K. Das Alter der Drachenbäume auf Tenerife. Flora 1975, 164, 347-357. [CrossRef]

117. Pütter, A. Altersbestimmung an Drachenbäumen von Tenerife. Sitz. Der Heidelb. Akad. Der Wissenschäften. Math.-Nat. Kl. 1925, 12, 12-18. 
118. Humboldt, A.v. Relation historique du Voyage aux Régions équinoctiales du Nouveau Continent; F. Schoell: Paris, France, 1814.

119. Christ, H. Eine Frühlingsfahrt zu den Canarischen Inseln; H. Georg's Verlag: Basel, Switzerland, 1886.

120. Schenck, H. Beitrage zur Kenntnis der Vegetation der Canarischen Inseln; Wissensch. Ergebn. d. dtsch. Tiefsee-Expedition "Valdivia", 2/1; Verlag G. Fischer,: Jena, Germany, 1907; pp. 225-406.

121. Nadezhdina, N.; Čermák, J.; Nadezhdin, V. Heat field deformation method for sap flow measurements. In Measuring Sap Flow in Intact Plants, 1st ed.; Čermák, J., Nadezhdina, N., Eds.; Mendel University: Brno, Czech Republic, 1998; pp. 72-92.

122. Nadezhdina, N.; Tributsch, H.; Čermák, J. Infra-red images of heat field around a linear heater and sap flow in stems of lime trees under natural and experimental conditions. Ann. For. Sci. 2004, 61, 203-213. [CrossRef]

123. Nadezhdina, N. Revisiting the Heat Field Deformation (HFD) method for measuring sap flow. Iforest-Biogeosci. For. 2018, 11, 118-130. [CrossRef]

124. Nadezhdina, N.; Al-Okaishi, A.; Madera, P. Long-term in situ sap flow monitoring in a mature Dracaena cinnabari tree on Socotra. Biologia 2019. [CrossRef]

125. Nadezhdina, N.; Nadezhdin, V. Are Dracaena nebulophytes able to drink atmospheric water? Environ. Exp. Bot. 2017, 139, 57-66. [CrossRef]

126. Nadezhdina, N.; Gebauer, R.; Nadezhdin, V.; Plichta, R. Water transport secrets of the dragon's blood trees revealed through sap flow measurements following partial stem incision. Flora 2019, 250, 44-51. [CrossRef]

127. Nadezhdina, N.; Al-Okaishi, A.; Madera, P. Sap flow measurements in a Socotra dragon's blood tree (Dracaena cinnabari) in its area of origin. Trop. Plant Biol. 2018, 11, 107-118. [CrossRef]

128. Nadezhdina, N.; Nadezhdin, V.; Gebauer, R.; Čermák, J.; David, J.S.; David, T.S.; Jimenez, M.S.; Morales, D. Redistribution of water within the aboveground part of trees. Acta Hortic. 2012, 951, 241-249. [CrossRef]

129. Sun, J.; Liu, J.N.; Fan, B.; Chen, X.N.; Pang, D.R.; Zheng, J.; Zhang, Q.; Zhao, Y.F.; Xiao, W.; Tu, P.F.; et al. Phenolic constituents, pharmacological activities, quality control, and metabolism of Dracaena species: A review. J. Ethnopharmacol. 2019, 224, 112138. [CrossRef]

130. Edward, H.G.M.; Oliveira, L.F.C.; Quye, A. Raman spectroscopy of coloured resins used in antiquity: dragon's blood and related substances. Spectrochim. Acta Part A 2001, 57, 2831-2842. [CrossRef]

131. Vaníčková, L.; Pompeiano, A.; Maděra, P.; Massad, TJ.; Vahalík, P. Terpenoid profiles of resin in genus Dracaena are species specific. Phytochemistry 2020, 170, 112197. [CrossRef]

132. González, A.G.; León, F.; Hernández, J.C.; Padrón, J.I.; Sánchez-Pinto, L.; Barrera, J.B. Flavans of dragon's blood from Dracaena draco and Dracaena tamaranae. Biochem. Syst. Ecol. 2004, 32, 179-184. [CrossRef]

133. Yi, T.; Chen, H.B.; Zhao, Z.Z.; Yu, Z.L.; Jiang, Z.H. Comparison of the chemical profiles and anti-platelet aggregation effects of two "Dragon's Blood" drugs used in traditional Chinese medicine. J. Ethnopharmacol. 2011, 133, 796-802. [CrossRef]

134. Israa, A.I.; Haider, M.H.; Imad, H.H. Bioactivities, characterization, and therapeutic uses of Dracaena cinnabari. Int. J. Pharm. Qual. Assur. 2018, 9, 11-14. [CrossRef]

135. Masaoud, M.; Schmidt, J.; Adam, G. Sterols and triterpenoids from Dracaena cinnabari. Phytochemistry 1995, 38, 795-796. [CrossRef]

136. Zheng, Q.A.; Li, H.Z.; Zhang, Y.J.; Yang, C.R. Dracaenogenins A and B, new spirostanols from the red resin of Dracaena cochinchinensis. Steroids 2006, 71, 160-164. [CrossRef]

137. Zheng, Q.A.; Zhang, Y.J.; Yang, C.R. A new meta-homoisoflavane from the fresh stems of Dracaena cochinchinensis. J. Asian Nat. Prod. Res. 2006, 8, 571-577. [CrossRef]

138. Hernández, J.C.; León, F.; Quintana, J.; Estévez, F.; Bermejo, J. Icogenin, a new cytotoxic steroidal saponin isolated from Dracaena draco. Bioorganic Med. Chem. 2004, 12, 4423-4429. [CrossRef]

139. Mimaki, Y.; Kuroda, M.; Ide Atsushi Kameyama, A.; Yokosuka, A.; Sashida, Y. Steroidal saponins from the aerial parts of Dracaena draco and their cytostatic activity on HL-60 cells. Phytochemistry 1999, 50, 805-813. [CrossRef]

140. Zheng, Q.A.; Zhang, Y.J.; Li, H.Z.; Yang, C.R. Flavonoids from Dragon's Blood of Dracaena cochinchinensis. Helv. Chim. Acta 2004, 87, 1267-1271. [CrossRef]

141. Zheng, Q.A.; Zhang, Y.J.; Li, H.Z.; Yang, C.R. Steroidal saponins from fresh stems of Dracaena cochinchinensis. Steroids 2004, 69, 111-119. [CrossRef]

142. Gurib-Fakim, A.; Demarne, F. Volatile constituents of Dracaena reflexa Lam. var. angustifolia Baker. J. Essent. Oil Res. 1994, 6, 651-652. [CrossRef] 
143. Santos, R.P.; Mendes, L.S.; Silva, B.M.; de Pinho, P.G.; Valentao, P.; Andrade, P.B.; Pereira, J.A.; Carvalho, M. Phytochemical profiles and inhibitory effect on free radical-induced human erythrocyte damage of Dracaena draco leaf: A potential novel antioxidant agent. Food Chem. 2011, 124, 927-934. [CrossRef]

144. Teng, Z.; Zhang, M.; Meng, S.; Dai, R.; Meng, W.; Deng, Y.; Huang, L. A comparative study on volatile metabolites profile of Dracaena cochinchinensis (Lour.) S.C. Chen xylem with and without resin using GC-MS. Biomed. Chromatogr. 2015, 29, 1744-1749. [CrossRef] [PubMed]

145. Masaoud, M.; Himmelreich, H.; Ripperger, H.; Adam, G. New bioflavonoids from Dracaena cinnabari. Planta Med. 1995, 61, 341-344. [CrossRef]

146. Masaoud, M.; Ripperger, H.; Himmelreich, U.; Adam, G. Cinnabarone, a biflavonoid from dragon's blood of Dracaena cinnabari. Phytochemistry 1995, 38, 751-753. [CrossRef]

147. Lu, W.J.; Wang, X.; Chen, J.; Lu, Y.; Wu, N.; Kang, W.; Zheng, Q. Studies on the chemical constituents of chloroform extract of Dracaena cochinchinensis. Acta Pharm. Sin. 1998, 33, 755-758.

148. Melo, M.J.; Sousa, M.; Parola, A.J.; de Melo, J.S.; Catarino, F.; Marcalo, J.; Pina, F. Identification of 7,4' -Dihydroxy-5-methoxyflavylium in "Dragon's Blood": To be or not to be an anthocyanin. Chemistry 2006, 13, 1417-1422. [CrossRef]

149. Veselá, D.; Marek, R.; Ubik, K.; Lunerová, K.; Sklenář, V.; Suchý, V. Dracophane, a metacyclophane derivative from the resin of Dracaena cinnabari Balf. Phytochemistry 2002, 61, 967-970. [CrossRef]

150. Zhou, Z.H.; Wang, J.L.; Yang, C.R. Cochinchinenin-a new chalcone dimer from the Chinese Dragon's blood. Acta Pharm. Sin. 2001, 36, 200-204.

151. Zhou, Z.H.; Wang, J.L.; Yang, C.R. Chemical constituents of Sanguis Draxonis made in China. Chin. Tradit. Herb. Drugs 2001, 32, 484-486.

152. Fischer, H.; Machen, T.E.; Widdicombe, J.H.; Carlson, T.J.; King, S.R.; Chow, J.W.; Illek, B. A novel extract SB-300 from the stem bark latex of Croton lechleri inhibits CFTR-mediated chloride secretion in human colonic epithelial cells. J. Ethnopharmacol. 2004, 93, 351-357. [CrossRef] [PubMed]

153. Gupta, D.; Gupta, R.K. Bioprotective properties of Dragon's blood resin: In vitro evaluation of antioxidant activity and antimicrobial activity. Bmc Complementary Altern. Med. 2011, 11, 13-17. [CrossRef] [PubMed]

154. Orozco-Topete, R.; Sierra-Madero, J.; Cano-Dominguez, C.; Kershenovich, J.; Ortiz- Pedroza, G.; Vazquez-Valls, E.; Garcia-Cosio, C.; Soria-Cordoba, A.; Armendariz, A.M.; Teran-Toledo, X. Safety and efficacy of Virend@for topical treatment of genital and anal herpes simplex lesions in patients with AIDS. Antiviriral Res. 1997, 35, 91-103. [CrossRef]

155. Wang, H.; Liu, J.; Wu, J.; Mei, W.L. Flavonoids from Dracaena cambodiana. Chem. Nat. Compd. 2011, 47, 624-626. [CrossRef]

156. Chen, Y.L.; Chen, S.; Liu, X.M. Experimental study on analgesic effect and block of nerve conduction induced by dragon's blood. Lishizhen Med. Mater. Med. Res. 2010, 21, 2446-2447. [CrossRef]

157. Machala, M.; Kubinova, R.; Horavova, P.; Suchy, V. Chemoprotective potentials of Homoisoflavonoids and Chalcones of Dracaena cinnabari: Modulations of Drug-metabolizing Ensymes and Antioxidant Activity. Phytother. Res. 2001, 15, 114-118. [CrossRef]

158. Al-Awthan, Y.S.; Zarga, M.A.; Abdalla, S. Flavonoids content of Dracaena cinnabari resin and effects of the aqueous extract on isolated smooth muscle preparations, perfused heart, blood pressure and diuresis in the rat. Jordan J. Pharm. Sci. 2010, 3, 8-17.

159. Eichholz, D.E.; Jones, W.H.S.; Rackham, H. Pliny: Natural History; with an English Translation in Ten Volumes; Jones, W.H.S., Rackham, H., Eds.; Harvard University Press: Cambridge, MA, USA, 1961; pp. 115-116.

160. Casson, L. The Periplus of the Erythraean Sea; Princeton University Press: Princeton, NJ, USA, 1989; p. 169.

161. Strauch, I. Foreign Sailors on Socotra: The Inscriptions and Drawings from the Cave HOQ.; Hempen: Bremen, Germany, 2012.

162. Lev, E.; Amar, Z. Practical materia medica of the medieval eastern Mediterranean according to the Cairo Genizah; Brill: Leiden, Germany, 2008; p. 400.

163. Al-Mujāwir, I. A Traveller in Thirteenth-century Arabia, Ibn al-Mujāwir's Tārīkh al-Mustabir; Translated from Oscar Löfgren's Arabic text and edited with revisions and annotations by G. Rex Smith; The Hakluyt Society: London, UK, 2008; p. 2264.

164. Hirth, F.; Rockhill, W. Chau Ju-Kua, his work on the Chinese and Arab Trade in the Twelfth and Thirteenth Centuries, entitled 'Chu-fan-chï'. St.; Imperial Academy of Sciences: Petersburg, Russia, 1911; pp. 130-132. 
165. Yāqūt, B.; Abd, A.R. Jacut's Geographisches Wörterbuch (Kitāb mu'jam al-buldān); Wüstenfeld, F., Brockhaus, F.A., Eds.; Deutsche Morgenlandische Gesellschaf: Leipzig, Germany, 1866; p. 6237.

166. Roe, T. The Embassy of Sir Thomas Roe to India, 1615-1619. (2 volumes); Foster, W., Ed.; The Hakluyt Society: London, UK, 1967; pp. 29-37.

167. Foster, W. The English Factories in India 1665-1667. (12 vols.); Clarendon Press: Oxford, UK, 1970; pp. $1906-1927$.

168. Hunter, F.M.; Sealey, C.W.H. An Account of the Arab Tribes in the Vicinity of Aden; Darf Publishers: London, UK, 1986; pp. 366-367.

169. Brown, G.H.H. Social and Economic Conditions and Possible Development of Socotra. Unpublished report. 1966; 29.

170. Wellsted, J.R. Memoir on the Island of Socotra. J. R. Geogr. Soc. 1835, 5, 129-229. [CrossRef]

171. Bent, T. Southern Arabia; Smith, Elder and Co.: London, UK, 1900; pp. 351-352.

172. Botting, D. The Oxford University Expedition to Socotra. Geogr. J. 1958, 124, 200-207. [CrossRef]

173. Shinnie, P.L. Socotra. Antiquity 1960, 34/134, 100-110. [CrossRef]

174. Doe., D.B. Socotra: An Archaeological Reconnaissance in 1967; Coconut Grove: Miami, Florida, USA, 1970.

175. Doe, D.B. Socotra Island of Tranquillity; Immel: London, UK, 1992.

176. Naumkin, V.V.; Sedov, A.V. Monuments of Socotra. Topoi 1993, 70, 569-623. [CrossRef]

177. Weeks, L.; Morris, M.; McCall, B.; Al-Zubairy, K. A recent archaeological survey on Soqotra. Report on the Preliminary Expedition Season,5 January-2 February 2001. Arab. Archaeol. Epigr. 2002, 13, 95-125. [CrossRef]

178. Jansen van Rensburg, J.; Hopper, K. Incense and imagery: Mapping agricultural and water management systems on the island of Socotra, Yemen. Proc. Semin. Arab. Stud. 2017, 47, 129-138.

179. Al-Fatimi, M. Ethnobotanical survey of Dracaena cinnabari and investigation of the pharmacognostical properties, antifungal and antioxidant activity of its resin. Plants 2018, 7, 91. [CrossRef]

180. Černý, V.; Pereira, L.; Kujanová, M.; Vašíková, A.; Hájek, M.; Morris, M.; Mulligan, J.C. Out of Arabia-The Settlement of Island Soqotra as Revealed by Mitochondrial and Y Chromosome Genetic Diversity. Am. J. Phys. Anthropol. 2009, 138, 439-447. [CrossRef] [PubMed]

181. Elnoby, S.K.; Abdelraouf, A. Moustafa; Samira, R. Mansour. Impact of climate change on the endangered Nubian dragon tree (Dracaena ombet) in the South Eastern of Egypt. Catrina 2017, 16, 23-28. [CrossRef]

182. 182. Abrha Tesfay Mehari. Ethnobotanical study of Dess'a forest, north-eastern escarpment of Ethiopia, with emphasis on use and management of forest resources by the local people. Master's Thesis, Addis Ababa University, Addis Ababa, Ethiopia, 2008.

183. Miller, A.G.; Morris, M. Plants of Dhofar, the Southern Region of Oman: Traditional, Economic and Medicinal uses, 1st ed.; Office of the Adviser for Conservation of the Environment, Diwan of Royal Court Sultanate of Oman Publishing: Sultanate of Oman, 1988; p. 16.

184. Mies, B. On the comparison of the flora and vegetation of the island groups of Socotra and Macaronesia. Bol. Do Mus. Munic. Do Funchal (História Nat.) 1995, 4, 455-471.

185. Kim, S.-C.; McGowen, M.R.; Lubinsky, P.; Barber, J.C.; Mort, M.E.; Santos-Guerra, A. Timing and tempo of early and successive adaptive radiations in Macaronesia. PLoS ONE 2008, 3, e2139. [CrossRef]

186. Cropper, T. The weather and climate of Macaronesia: Past, present and future. Weather 2013, 68, 300-307. [CrossRef]

187. Marzol, V.M.; Sánchez, J.L.; Yanes, A. Meteorological patterns and fog water collection in Morocco and the Canary Islands. Erdkunde 2011, 65, 291-303. [CrossRef]

188. Médail, F.; Quézel, P. The phytogeographical signifikance of S. W. Morocco compared to the Canary Islands. Plant Ecol. 1999, 140, 221-244. [CrossRef]

189. Beyhl, F.E. The Emta tree (Euphorbia arbuscula Balf. fil.), a succulent tree of dracoid habitus from the island of Soqotra (Dicotyledones: Tricococcae: Euphorbiaceae). In Proceedings of the First International Symposium on Soqotra Island: Present and Future; Dumont, H.J., Ed.; United Nations Publications: New York, NY, USA, 1996; pp. 115-123.

190. Costa, J.C.; Neto, C.; Aguiar, C.; Capelo, J.; Espírito Santo, M.D.; Honrado, J.; Pinto-Gomes, C.; Monteiro-Henriques, T.; Sequeira, M.; Lousã, M. Vascular plant communities in Portugal (Continental, Azores and Madeira). Glob. Geobot. 2012, 2, 1-180. [CrossRef]

191. Olehowski, C.; Naumann, S.; Fischer, D.; Siegmund, A. Geo-ecological spatial pattern analysis of the island of Fogo (Cape Verde). Glob. Planet. Chang. 2008, 64, 188-197. [CrossRef] 
192. Rivas-Martínez, S.; Lousã, M.; Costa, J.C.; Duarte, M.C. Geobotanical survey of Cabo Verde Islands (West Africa). Int. J. Geobot. Res. 2017, 7, 1-103. [CrossRef]

193. Kassas, M. The mist oasis of Erkwit, Sudan. J. Ecol. 1954, 44, 180-194. [CrossRef]

194. Kürschner, H.; Hein, P.; Kilian, N.; Hubaishan, M.A. Diversity and zonation of the forests and woodlands of the mountains of northern Socotra, Yemen. Englera 2006, 28, 11-55. [CrossRef]

195. De Sanctis, M.; Adeeb, A.; Farcomeni, A.; Patriarca, C.H.; Saed, A.; Attorre, F. Classification and distribution patterns of plant communities on Socotra Island, Yemen. Appl. Veg. Sci. 2013, 16, 148-165. [CrossRef]

196. Habrová, H.; Buček, A. Overview of biotope types of Socotra Island. J. Lansdscape Ecol. 2013, 6, 60-83. [CrossRef]

197. Abd El-Ghani, M.M.; Abdel-Khalik, K.N. Floristic Diversity and Phytogeography of the Gebel Elba National Park, South-East Egypt. Turk. J. Bot. 2006, 30, 121-136.

198. Aynekulu, E.; Aerts, R.; Moonen, P.; Denich, M.; Gebrehiwot, K.; Vagen, T.G.; Mekuria, W.; Boehmer, H.J. Altitudinal variation and conservation priorities of vegetation along the Great Rift Valley escarpment, northern Ethiopia. Biodivers. Conserv. 2012, 21, 2691-2707. [CrossRef]

199. Mwachala, G. Systematics and Ecology of Dracaena L. (Ruscaceae) in Central, East and Southern Africa. Ph.D. Thesis, University of Koblenz-Landau, Mainz, Germany, 2005.

200. Van Breugel, P.; Friis, I.; Demissew, S. The transitional semi-evergreen bushland in Ethiopia: Characterization and mapping of its distribution using predictive modelling. Appl. Veg. Sci. 2016, 19, 355-367. [CrossRef]

201. Friis, I.; Gilbert, M.G.; van Breugel, P.; Weber, O.; Demissew, S. Kalanchoe hypseloleuce (Crassulaceae), a new species from eastern Ethiopia, with notes on its habitat. Kew Bull. 2017, 72, 30. [CrossRef]

202. Zhu, H. Forest vegetation of Xishuangbanna, south China. For. Stud. China 2006, 8, 1-58. [CrossRef]

203. Zheng, D.J.; Li, H.W.; Yun, Y.; Zhang, L.; Zhang, Z.L. Investigation on the habitat and natural regeneration capacity of Dracaena cambodiana. J. Trop. Subtrop. Bot. 2010, 18, 627-632.

204. Geekiyanage, N.; Goodale, U.M.; Cao, K.; Kitajima, K. Plant ecology of tropical and subtropical karst ecosystems. Biotropica 2019, 1-15. [CrossRef]

205. Almeida Pérez, R.S. Dracaena tamaranae Marrero Rodr., R.S. Almeida \& M. González-Martín. In Atlas y Libro Rojo de la Flora Vascular Amenazada de España, 2nd ed.; Bañares, A., Blanca, G., Güemes, J., Moreno, J.C., Ortiz, S., Eds.; Publicaciones de O.A.P.N.: Madrid, Spain, 2004; pp. 226-227.

206. Almeida Pérez, R.S. Dracaena draco (L.) L. In Atlas y Libro Rojo de la Flora Vascular Amenazada de España, 2nd. ed.; Bañares, A., Blanca, G., Güemes, J., Moreno, J.C., Ortiz, S., Eds.; Publicaciones de O.A.P.N.: Madrid, Spain, 2004; pp. 680-681.

207. Adolt, R.; Maděra, P.; Abraham, J.; Čupa, P.; Svrátek, M.; Matula, R.; Šebesta, J.; Čermák, M.; Volařík, D.; Koutecký, T.; et al. Field survey of Dracaena cinnabari populations in Firmihin, Socotra island: Methodology and preliminary results. J. Landsc. Ecol. 2013, 6, 7-34. [CrossRef]

208. Vetaas, O.R. Spatial and temporal vegetation changes along a moisture gradient in Northeastern Sudan. Biotropica 1993, 25, 164-175. [CrossRef]

209. Van Rampellbergh, M.; Fleitmann, D.; Verheydeno, S.; Cheng, H.; Edwards, L.; De Geest, P.; De Vleeschouwer, D.; Burns, J.S.; Matter, A.; Claeys, P.; et al. Mid- to late holocene Indian ocean monsoon variability recorded in four speleothems from Socotra island, Yemen. Quat. Sci. Rev. 2013, 65, 129-142. [CrossRef]

210. Marrero, A.; Almeida, R.S.; Roca, A. Diáspora y rescate: Acciones para la conservación del Drago de Gran Canaria, Dracaena tamaranae; Poster, V., Ed.; Congreso de Biología de la Conservación de Plantas: Balearic Islands, Spain, 2011.

211. Chen, X.; Zhang, Z.; Yang, L.; Yun, Y.; Chen, J.; Zheng, D. Effects of light intensity on phenotypic plasticity and survival strategy of Dracaena cambodiana seedlings. J. Trop. Subtrop. Bot. 2018, 26, 150-156. [CrossRef]

212. Moreno, J.C. (Ed.) Lista Roja 2008 de la flora vascular española, 1st ed.; Dirección General de Medio Natural y Política Forestal: Madrid, Español, 2008; p. 86.

213. Galus, A.; Bouket, A.C.H.; Belbahri, L. In vitro propagation and acclimatization of Dragon Tree (Dracaena draco). Horticulturae 2019, 5, 64. [CrossRef] 
214. Al Hosni, A.; Oliver, I.; Al Jabri, Y.; Al Saidi, A.; Al Rawahi, A.; Al Hinai, H. Ex situ conservation of Dracaena serrulata in Dhofar province, southern Oman. Acta Hortic. 2018, 1190. [CrossRef]

215. Schweiger, A.H.; Irl, S.D.H.; Svenning, J.C.H.; Higgins, S.I. Dynamic management needs for long-lived, sporadically recruiting plant species in human-dominated landscapes. Plants People Planet 2020, 1-15. [CrossRef] 